WIDER Working Paper 2016/160

\title{
Regional opportunities in East Africa
}

Stephen Karingi, ${ }^{1}$ Ottavia Pesce, ${ }^{2}$ and Lily Sommer ${ }^{3}$

December 2016 
Abstract: Significant progress has been made by the East African Community partner states in implementing the East African Community customs union. Trade within the East African Community is now free from import duties, and partner states have adopted a three-band common external tariff. This paper assesses how the customs union has supported intraregional trade and industrialization, in particular through the development of competitive smokestack-free industries. It concludes that regional integration has provided a support environment for the development of smokestack-free industries, but significant opportunities still exist within the region. Recommendations are provided on what should be done to harness these opportunities.

Keywords: exports, free trade, customs union, competitiveness, East African Community, industrialization

JEL classification: F13, F14, F15, F23, L6, O19

Acknowledgements: The authors wish to sincerely thank representatives of the Dairy Development Authority, the Ministry of Agriculture, Animal Industry, and Fisheries, Jesa Farm Dairy Limited and Brookside Limited, who participated in the field visit meetings in Uganda. The information and experiences shared during this exercise provided very valuable input into the case study on the Ugandan dairy industry presented in Section 5.

The views expressed in this paper are the authors' own and may not necessarily reflect the position of the United Nations Economic Commission for Africa and the United Nations Economic and Social Commission for Western Asia. Any mistakes or omissions are the sole responsibility of the authors.

\footnotetext{
${ }^{1}$ Capacity Development Division, United Nations Economic Commission for Africa, Addis Ababa, Ethiopia; ${ }^{2}$ Economics Development and Globalization Division, United Nations Economic and Social Commission for Western Asia, Beirut, Lebanon; ${ }^{3}$ Regional Integration and Trade Division, United Nations Economic Commission for Africa, Addis Ababa, Ethiopia, corresponding author: skaringi@uneca.org.
}

This study has been prepared within the UNU-WIDER project on 'Industries without smokestacks', which is part of a larger research project on 'Jobs, poverty and structural change in Africa'.

Copyright (C) UNU-WIDER 2016

Information and requests: publications@wider.unu.edu

ISSN 1798-7237 ISBN 978-92-9256-204-5

Typescript prepared by Gary Smith.

The United Nations University World Institute for Development Economics Research provides economic analysis and policy advice with the aim of promoting sustainable and equitable development. The Institute began operations in 1985 in Helsinki, Finland, as the first research and training centre of the United Nations University. Today it is a unique blend of think tank, research institute, and UN agency — providing a range of services from policy advice to governments as well as freely available original research.

The Institute is funded through income from an endowment fund with additional contributions to its work programme from Denmark, Finland, Sweden, and the United Kingdom.

Katajanokanlaituri 6 B, 00160 Helsinki, Finland

The views expressed in this paper are those of the author(s), and do not necessarily reflect the views of the Institute or the United Nations University, nor the programme/project donors. 
This paper assesses how a well-integrated economic bloc, the East African Community (EAC), has supported industrialization, in particular through smokestack-free industries.

The key objectives are to assess the impact of the EAC Customs Union (CU) and regional integration efforts more broadly on the:

- volume and type of intra-EAC trade;

- development of regional value chains (RVCs), particularly in smokestack-free industries; and

- development of competitive smokestack-free industries.

After looking at how regional integration has contributed to trade, RVCs, and industrial performance in the region, the paper describes some examples of smokestack-free industries that recently emerged in the EAC. It then delves into a case study of the dairy industry in Uganda, which expanded significantly over the last decade, partially thanks to tariff protection and export opportunities within the EAC.

The paper focuses on the $\mathrm{CU}$ as an instrument as it has been in full operation for over five years, whereas implementation of the Common Market (CM) Protocol has been slow and the EAC Monetary Union is yet to be established. Analysis is centred on the five 'established' EAC partner states in order to assess the overall impact of the EAC on boosting structural transformation, intraEAC trade, and RVCs, and the development of smokestack-free industries. Smokestack-free industries are taken as industries that display firm characteristics similar to traditional manufacturing industries, but are more modern and do not have the drawbacks associated with heavy polluting industries. Examples include agro-processing and tradeable services.

The EAC's trade agreements with other African countries and the rest of the world are not covered in detail. Although external EAC trade agreements have important implications for the region's trade and structural transformation, this is not the focus of the paper.

\section{Overview of the EAC}

\subsection{Background to the EAC}

The EAC came into force on 7 July 2000, following ratification by the original three founding partner states-Kenya, Tanzania, and Uganda. Rwanda and Burundi entered seven years later, on 1 July 2007; on 2 March 2016 South Sudan was admitted as the sixth member of the regional bloc. The EAC objective is to deepen economic, political, and social cooperation among members.

The EAC CU became operational in 2005 and initially covered Kenya, Tanzania, and Uganda. Rwanda and Burundi joined in 2008 and started to apply its instruments in 2009. It intends to liberalize intra-EAC trade and promote efficiency in production through facilitating the free movement of goods within the community. The EAC CM entered into force in 2010 following ratification by all five partner states. The $\mathrm{CM}$ aims to achieve the free movement of services, labour and capital, in addition to the free movement of goods. 
The key aspects of the $\mathrm{CU}$ are:

1 a common external tariff (CET) on imports from third countries;

2 duty-free trade between partner states; and

3 common customs procedures.

Significant progress has been made in the implementation of the CU. Trade between members is now free from import duties. ${ }^{1}$ Members adopt the three-band CET shown in Table 1. The maximum tariff under the CET is 25 per cent, although the EAC allows higher tariffs for a list of sensitive products, which are analysed in Section 3.2.

Table 1: Structure of EAC CET band rates

\begin{tabular}{lccc}
\hline & $\begin{array}{c}\text { EAC most-favoured nation } \\
\text { (MFN) tariff rates applied } \\
(\%)\end{array}$ & No. tariff lines & $\begin{array}{c}\text { Tariff lines } \\
(\%)\end{array}$ \\
\hline $\begin{array}{l}\text { Raw materials, capital goods, agricultural } \\
\text { inputs, certain medicines, and certain medical } \\
\text { equipment, etc. }\end{array}$ & 0 & 2,003 & 37.1 \\
$\begin{array}{l}\text { Intermediate goods and other essential } \\
\text { industrial inputs }\end{array}$ & 10 & 1,152 & 21.4 \\
Finished products & 25 & 2,176 & 40.3 \\
EAC sensitive items & $35-100$ & 64 & 1.2 \\
\hline
\end{tabular}

Source: World Bank et al. 2014.

The EAC CM became formally operational in July 2015 following a five-year transition period, but much is still to be desired in terms of implementation, particularly in the harmonization of national laws. In 2014, the EAC launched a new Scorecard to assess progress towards developing the EAC $\mathrm{CM}$. The Scorecard identified 63 non-conforming measures in the trade of services, and 51 nontariff barriers affecting trade in goods; it also pointed out that only two out of the 20 capital operations covered by the CM Protocol were free from restrictions in all member states (World Bank et al. 2014).

Based on its linear progress towards full economic union, the EAC is often considered the most advanced and ambitious regional economic community in Africa. Quantitative exercises by the International Growth Centre find significant trade promotion and security gains from the EAC (Mayer and Thoenig 2016). However, the EAC, and indeed Africa as a whole, trades less as a share of gross domestic product (GDP) than other developing regions such as East Asia and Latin America - this holds for both world trade and intraregional trade. Intra-EAC trade as a share of total trade also underperforms compared to other developing regions. For example, intra-EAC exports were 18 per cent of total EAC exports in 2014, whereas exports among developing economies in Eastern Asia as a share of total exports were 31 per cent.

A reason for this is the high prevalence of non-tariff barriers (NTBs) in the region, which create considerable obstacles to trade. This is reflected in the extremely high average costs in ad valorem equivalent for EAC countries to trade within the region, which were 118.8 per cent in $2013 .^{2}$ Prominent NTBs include high transport costs, bureaucracy, corruption, and expensive settlement of payments. The Economist (2013) estimates that shipping a car from China to Tanzania on the Indian Ocean costs US $\$ 4,000$, whereas transporting it from Tanzania to Uganda can cost

\footnotetext{
${ }^{1}$ With the exception of a few instances in which disagreements between partner states have arisen.

2 Authors' calculation based on the ESCAP-World Bank Trade Cost Database.
} 
US\$5,000. Transparency International's 2011 survey of East Africa's transport corridors uncovered significant levels of bribery, usually as a result of unnecessary delays (e.g., large amounts of documentation, slow pace of services, poor understanding of clearing procedures, and high tax levels). In Tanzania such bribes constituted about 18.6 per cent of the total value of goods transported (Transparency International 2012).

\subsection{Economic structure and performance}

All EAC partner states are classified as low-income countries, apart from Kenya, which recently transitioned into lower middle-income status. Four of the EAC partner states (Burundi, Rwanda, South Sudan, and Uganda) are landlocked, making cross-border ties and initiatives even more important for the region. Table 2 provides a snapshot of key economic and social indicators for the five established partner states.

Table 2: Key economic and social indicators for the EAC partner states

\begin{tabular}{|c|c|c|c|c|c|}
\hline & Burundi & Kenya & Rwanda & Tanzania & Uganda \\
\hline $\begin{array}{l}\text { Poverty headcount (percentage } \\
\text { of population) }\end{array}$ & 66.9 & 45.9 & 44.9 & 28.2 & 19.7 \\
\hline Life expectancy at birth (years) & 54 & 62 & 64 & 61 & 59 \\
\hline $\begin{array}{l}\text { Gross national income } \\
\text { per capita (current US\$) }\end{array}$ & 270 & 1,290 & 700 & 930 & 680 \\
\hline GDP growth (percentage) & 4.7 & 5.3 & 7.0 & 7.0 & 4.5 \\
\hline GDP (current US\$ billion) & 3.1 & 60.9 & 7.9 & 49.2 & 26.3 \\
\hline
\end{tabular}

Note: poverty headcount data use national poverty lines and were initially sourced from National Household Surveys; these refer to 2005 for Kenya, 2009 for South Sudan, 2011 for Tanzania, 2010 for Rwanda, 2012 for Uganda, and 2006 for Burundi. Life expectancy data are for 2013. All other data are for 2014. GNI per capita data use the Atlas method.

Source: World Development Indicators, data accessed 2 March 2016.

During the past decade, economic growth in the five established EAC partners was consistently strong and above that of previous decades (see Figure 1). This performance was driven by improvements in macroeconomic and political stability and by a more conducive environment for private sector growth, but also by enhanced regional integration. 
Figure 1: EAC GDP growth rates, 1993-2003 average compared to 2004-14 average

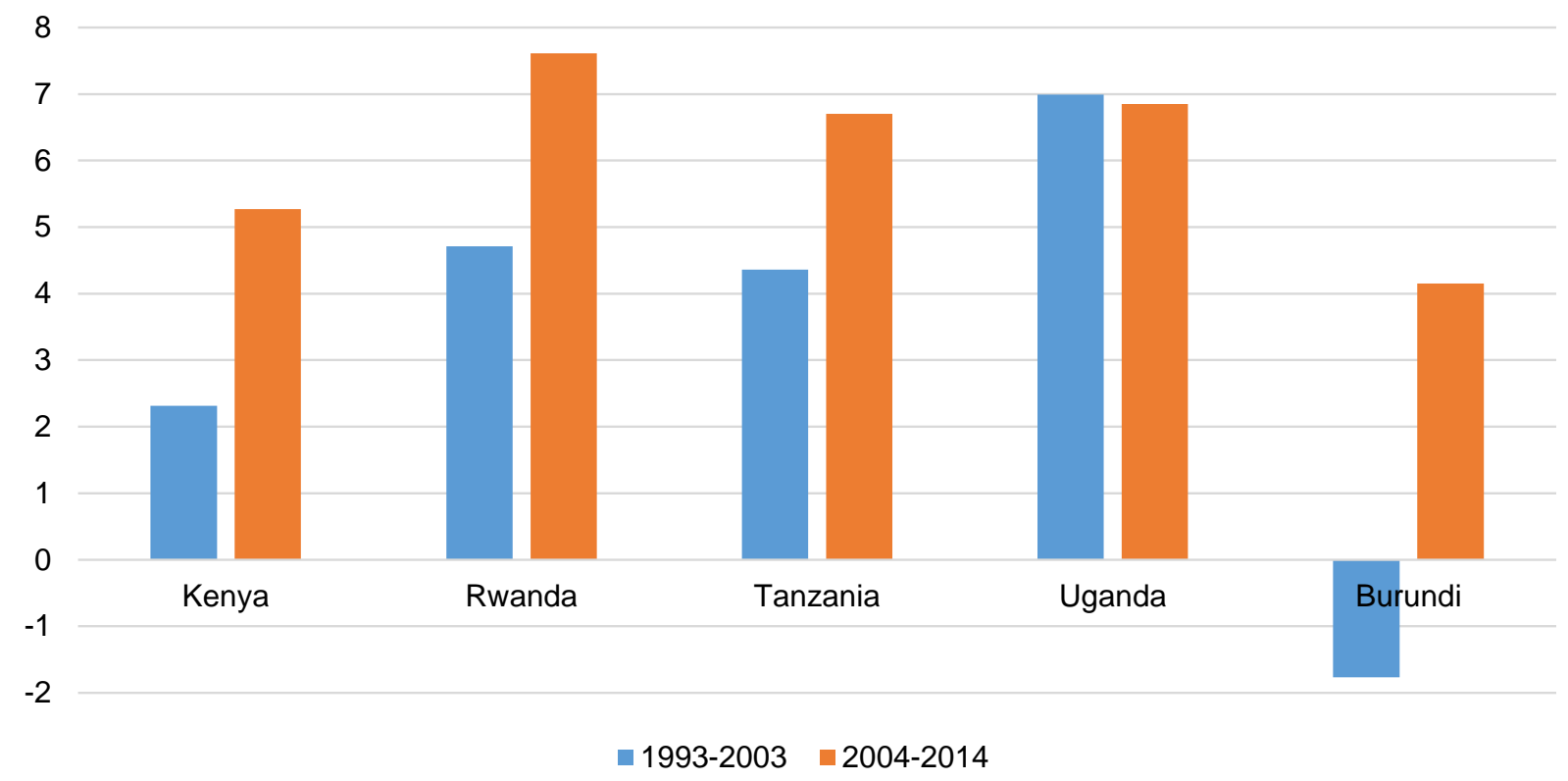

Source: authors' analysis based on World Bank data.

In 2015, East Africa was the continent's fastest-growing region, growing at 6.5 per cent compared to 3.7 per cent for Africa as a whole. According to the 2016 African Economic Outlook, this high growth is expected to continue. Although the region still produces and exports predominantly lowvalue primary products such as coffee and tea, the level of economic diversity and the number of smokestack-free industries in the EAC is increasing. Success stories cover sectors as diverse as cut flowers, dairy, textiles, financial services, information technology, and tourism.

The region benefits from large and increasing foreign direct investment (FDI) inflows and its development prospects were recently enhanced by natural resource discoveries. The EAC CU presents opportunities for firms to locate within the large EAC market and benefit from the single market. Annual FDI inflows to the region increased from US\$680 million in 2004 prior to the CU to US $\$ 4,577$ million in 2014. The EAC's FDI inflows as a share of Africa's total FDI inflows increased from 3.8 per cent to 8.5 per cent over the same period. FDI investments are largely concentrated in Tanzania and Uganda, which received 47 per cent and 25 per cent of the EAC's FDI inflows, respectively, in 2014. Intra-EAC FDI exists in smokestack-free industries such as financial services, tourism, and manufacturing (ILEAP 2012), and also in cement production, which is a crucial input to some smokestack-free industries.

\section{EAC performance}

\subsection{Trade in goods}

Intra-EAC exports registered a considerable upward trend following the implementation of the CU in 2005, increasing from US $\$ 912$ million in 2004 to US $\$ 2,509$ million in 2014. Kenya exports the most value to the EAC, followed by Uganda and Tanzania. Rwanda and Burundi have seen exports to EAC partner states increase, but this has been from a much lower base (see Figure 2). 
Figure 2: EAC internal and global exports by partner state (US\$ thousands)

\section{EAC global exports}

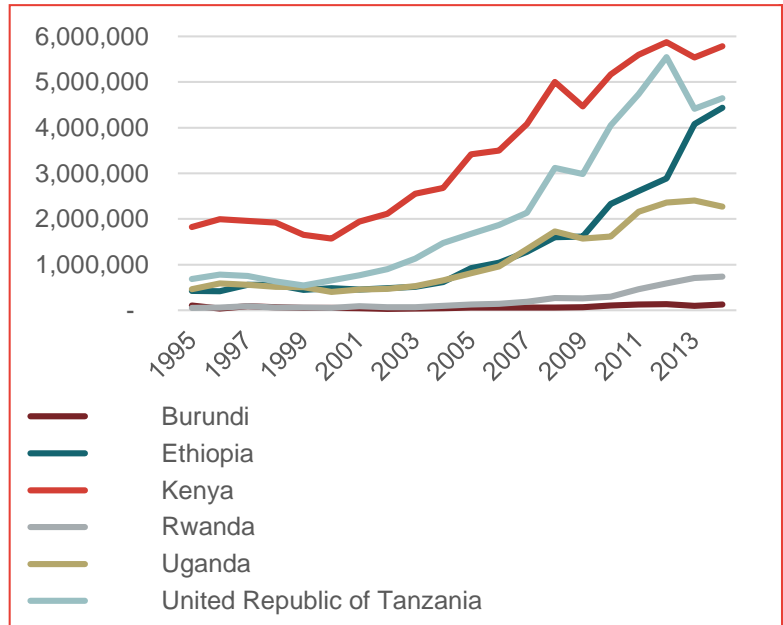

$20,000,000$

$15,000,000$

$10,000,000$

$5,000,000$

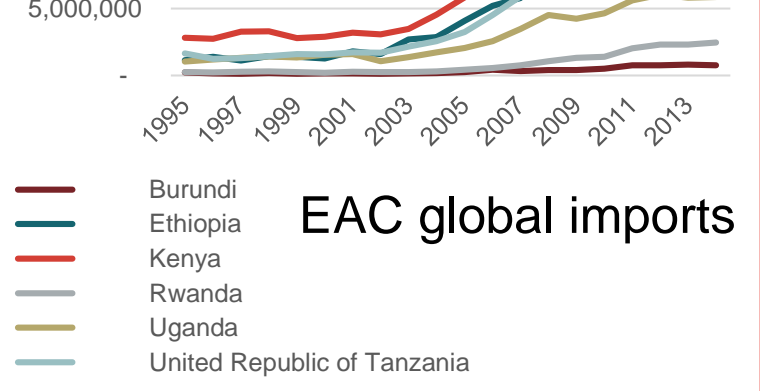

EAC internal exports

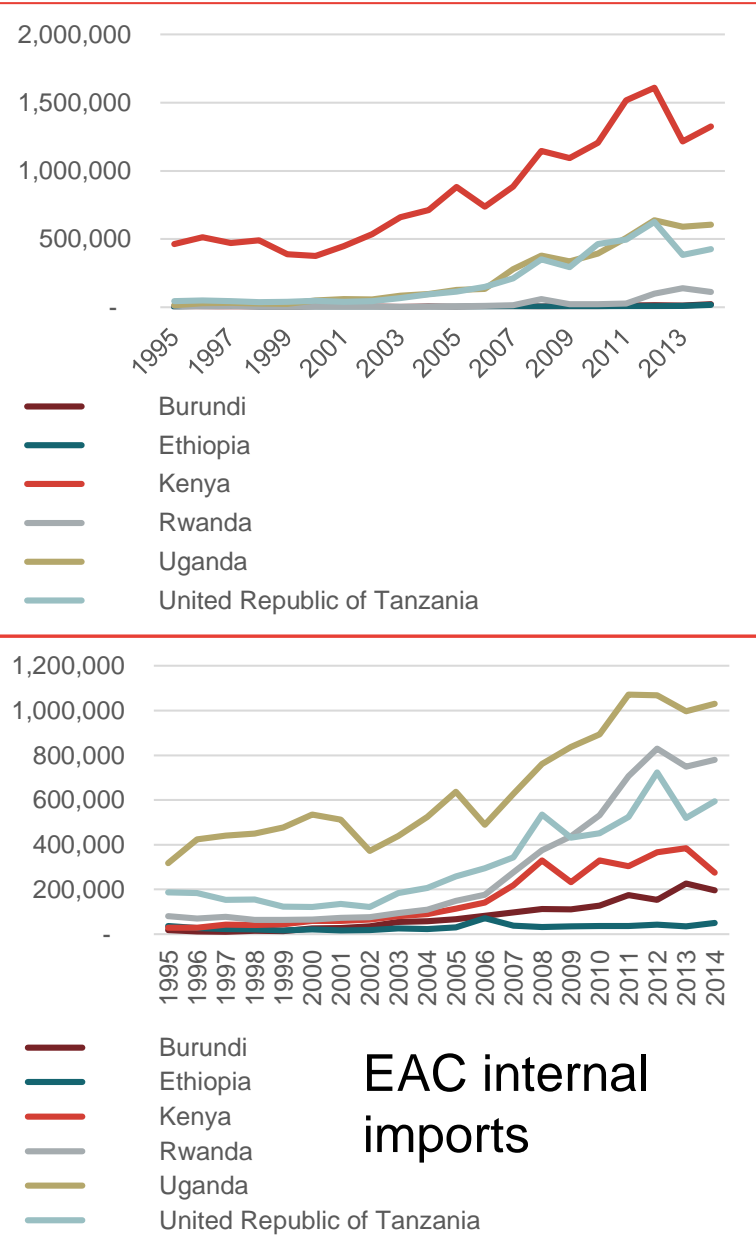

Source: UNCTADstat, accessed 18 June 2016.

The value of total intra-EAC imports is also on an upward trend, having increased from US $\$ 1,223$ million in 2005 to US $\$ 2,875$ million in 2014 (see Figure 2). Imports are, however, less integrated within the EAC than exports. In 2014 intra-EAC exports as a share of total EAC exports was 18 per cent, whereas intra-EAC imports as a share of total EAC imports was just 7 per cent. This is less than the figure of 10 per cent for 2005, reflecting the EAC's growing reliance on imports from the rest of the world. The growing demand for imports is driven by partner states' structural transformation agendas which require imported industrial goods, construction materials, and equipment-manufactured goods represent the largest share of the EAC's imports. Most of this demand is met through external trading partners due to the relatively low technological base of EAC partner states. Uganda, Rwanda, and Tanzania import the most from within the EAC, while Kenya, the group's most advanced economy, relies more on imports from the rest of the world.

On average, intra-EAC exports as a share of total EAC exports remained largely unchanged following implementation of the $\mathrm{CU}$ (see Figure 3). Kenya decreased its exports to the EAC as a share of total exports after joining the CU. This reflects the significant expansion of Kenya's trade with other African countries outside the EAC. On the other hand, Uganda is the country that expanded its EAC share of total exports the most after joining the CU. 
Figure 3: Exports shares before and after accession to the $\mathrm{CU}$, by partner state (percentages)

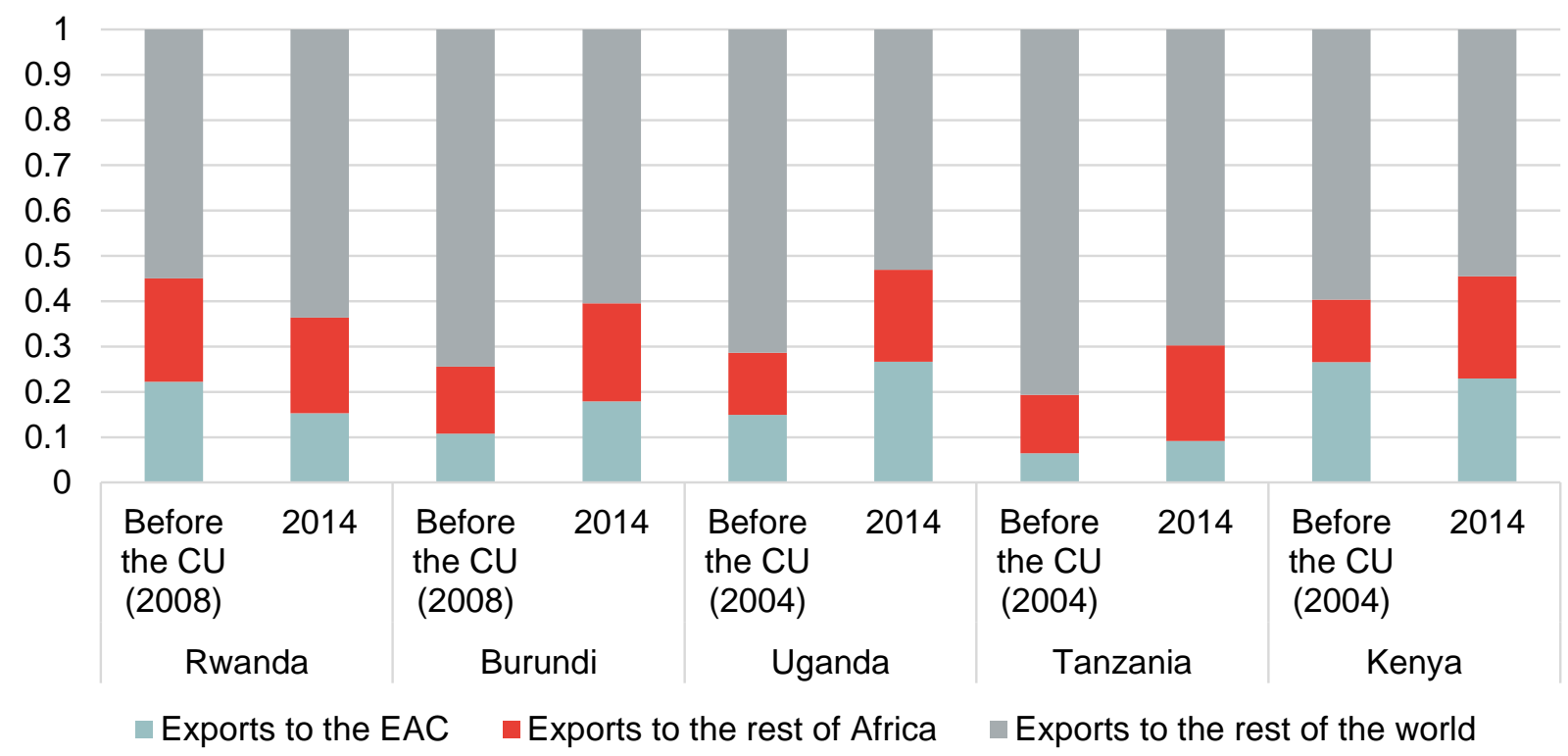

Source: authors' calculations based on UNCTADstat.

Increased regional integration has helped EAC partner states to diversify and structurally transform their economies. In 2014, EAC exports to the rest of the world were largely food items (48 per cent) and other non-manufactured goods-fuels, pearls, precious stones and nonmonetary gold, agricultural raw materials, and ores and metals (32 per cent). Intra-EAC exports are much more diversified than EAC's global exports, with a larger share of manufactured goods (55 per cent compared to 19 per cent), as shown in Figure 4. For example, in 2015 US $\$ 73$ million worth of lime, cement, and other construction materials were exported from Uganda to Rwanda. Coffee, tea, and spices contribute 20 per cent of EAC's exports to the rest of the world, but only 5 per cent to internal exports.

In 2014, 65 per cent of EAC's imports from the rest of the world were manufactured goods compared to 62 per cent for intra-EAC imports. The two percentages are very close, suggesting that EAC partner states have competitive import opportunities for manufactured goods within the region, despite still importing the majority of manufactures from outside. 
Figure 4: Trade within the EAC and with the rest of the world by product, 2014

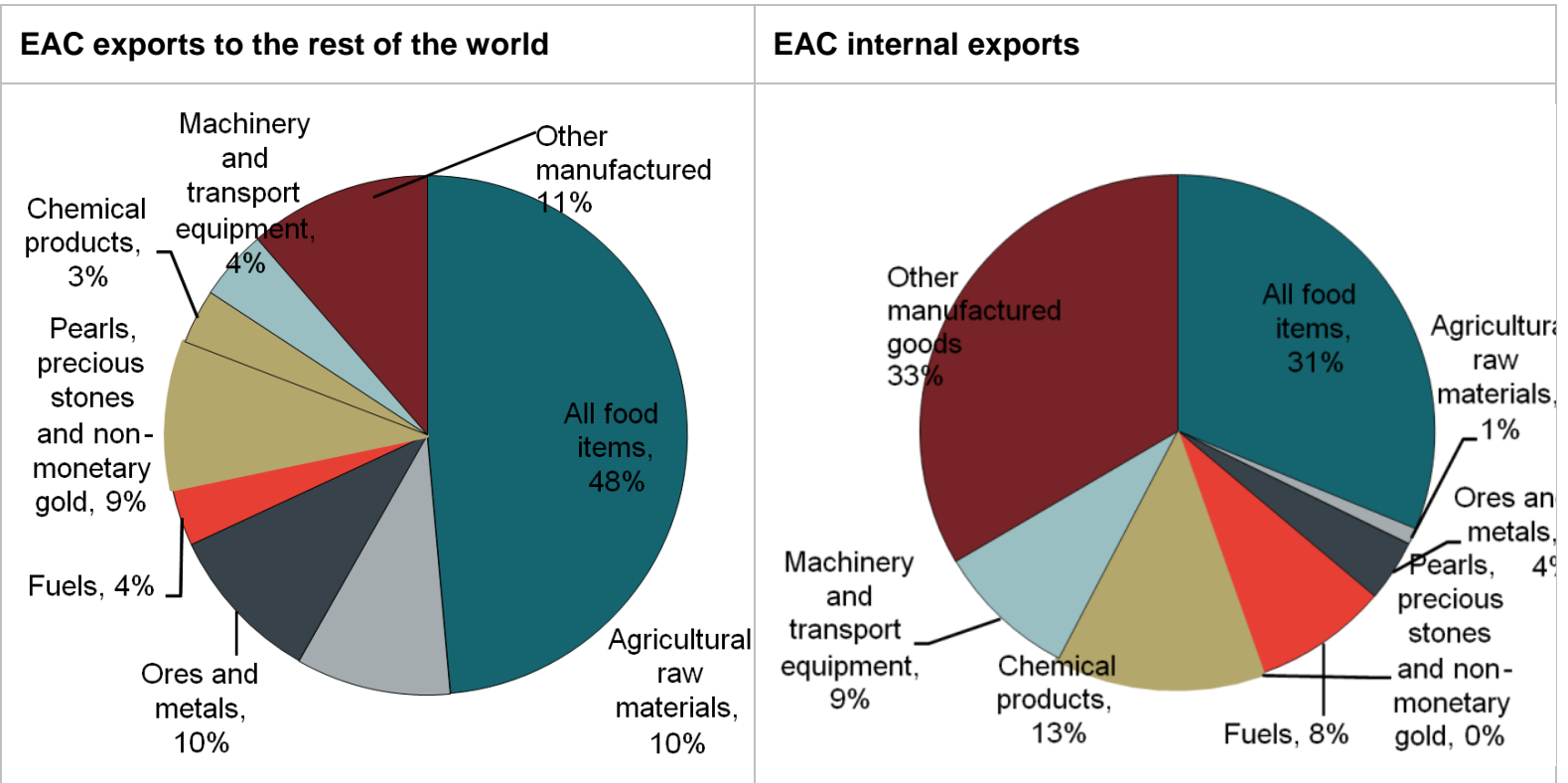

EAC imports from the rest of the world

EAC internal imports
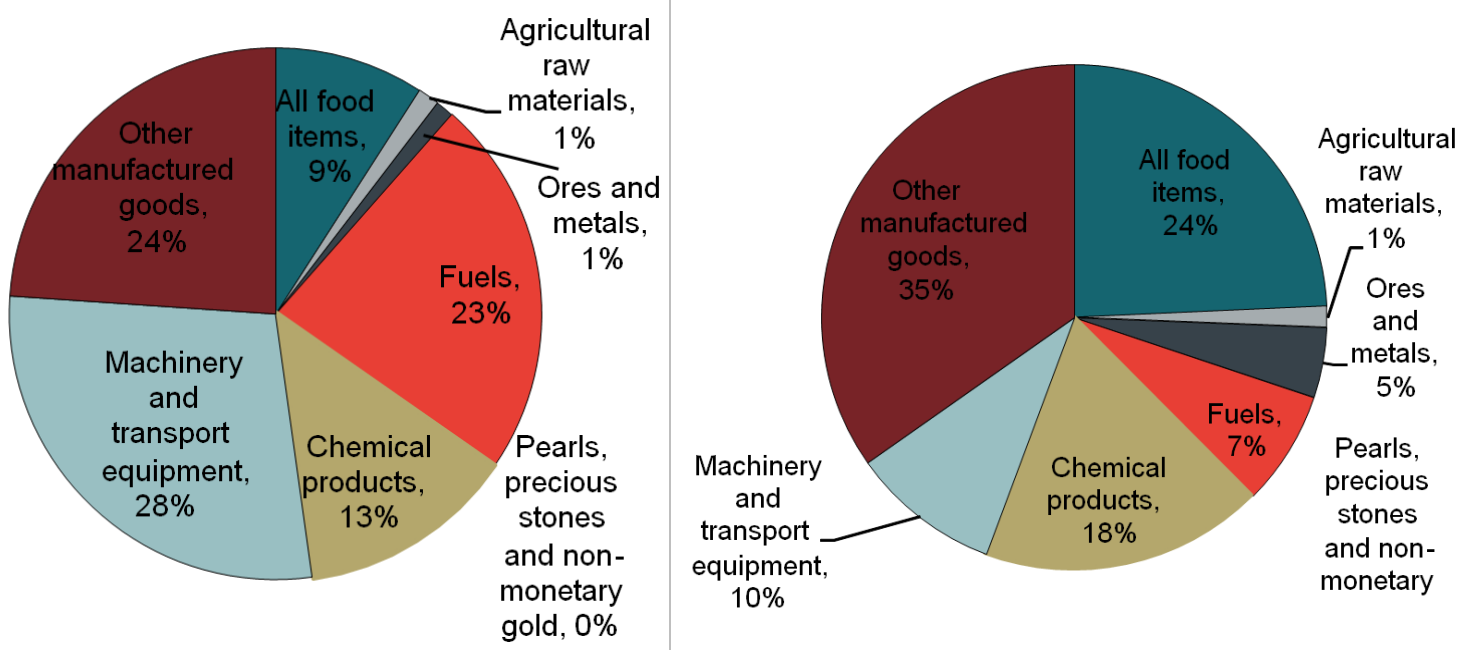

Source: authors' analysis of United Nations Conference on Trade and Development (UNCTAD) data, extracted 14 July 2016.

The level of trade between the EAC and other African countries is roughly the same as intra-EAC trade; however, the internal African market offers about 1,185 million people compared to the EAC market of only about 163 million people. ${ }^{3}$ This reflects the achievement of the EAC's regional integration process and the close proximity of EAC partner states to one another, but it also points to the need for greater integration within Africa. Tariff protection within Africa averages about 8.7 per cent compared to just 2.5 per cent to the rest of the world.

The Economic Community of West African States subregion has an internal market of about 349 million people, presenting significant export market opportunities for the EAC. ${ }^{4}$ West Africa presently relies on extra-African imports of coffee and tea, and the EAC would be well-placed to

${ }^{3}$ Data for 2015 from UNCTADstat.

${ }^{4}$ Data for 2015 from UNCTADstat. 
tap into this market if trade facilitation improved and high tariffs were eliminated through the Continental Free Trade Area (CFTA) planned for 2017. Modelling exercises by the Economic Commission for Africa (ECA) find strong positive potential impacts of the CFTA on intra-African trade, real incomes, and Africa's industrialization (ECA 2012). Also, Kenya and Nigeria-largest economies in East Africa and West Africa respectively-signed trade pacts in 2014 aimed at deepening trade ties between the two countries (Soininen 2014).

\subsection{Free trade area and CET structure}

The introduction of the three-band CET tariff structure differentially impacted EAC partner states. At the onset of the CU, Kenya adopted a ten-band tariff structure ranging from 0 to 100 per cent; Tanzania adopted a five-band tariff structure ranging from 0 to 25 per cent; and Uganda adopted a four-band tariff structure ranging from 0 to 30 per cent.

Table 3 shows the estimated effects on the three EAC partner states of implementing the CU 0 10-25 three-band CET structure. The CET resulted in a large reduction in Kenya's protection visà-vis the rest of the world, which helps to explain the growth and reorientation of Kenya's trade with countries outside of the EAC, as shown in Section 3.1. The majority of tariff lines were raised in Uganda. This increased the country's average costs from importing outside the EAC and helps to explain why Uganda imports the most from within the region.

Table 3: Estimated effects of CET tariff changes on EAC partner states

\begin{tabular}{lccc}
\hline & Kenya & Tanzania & Uganda \\
\hline Number of tariffs lowered & 3,216 & 2,364 & 1,353 \\
Number of tariffs increased & 1,144 & 1,224 & 3,066 \\
Number unchanged & 753 & 1,525 & 694
\end{tabular}

Source: McIntyre (2005).

Over time, EAC partner states progressively reduced internal tariffs. Table 4 shows that in 2003 Kenya imposed much higher tariff rates on imports from EAC partner states than did Tanzania and Uganda. The introduction of free trade between the three countries in 2005 therefore required the largest tariff reductions in Kenya, which already had relatively easy access to other EAC markets. The CU took into consideration the differing levels of development among partner states: it permitted Tanzania and Uganda to eliminate tariffs on all imports excluding an agreed list of commodities, for which tariffs on Kenyan imports would be gradually reduced to zero over a fiveyear period. This temporary protection mechanism was designed to allow Tanzanian and Ugandan producers sufficient time to restructure operations in the face of increased competition from Kenyan imports. The asymmetrical opening up to EAC imports - with significant opening up of the previously relatively closed Kenyan market-helps to explain why the share of Ugandan and Tanzanian exports to the EAC increased following the introduction of the $\mathrm{CU}$, while the share of Kenyan exports to the EAC declined. Burundi and Rwanda only joined the CU in 2009. As the two smallest economies in the region, this significantly opened up export opportunities to the larger EAC markets. 
Table 4: Evolution of intra-EAC tariff regimes (percentages)

\begin{tabular}{lccc}
\hline & 2003 & 2007 & 2010 \\
\hline $\begin{array}{lccc}\text { Burundi } \\
\text { Weighted average }\end{array}$ & 5.9 & 2.0 & 0.0 \\
$\begin{array}{l}\text { Maximum rate } \\
\text { Kenya }\end{array}$ & 40.0 & 30.0 & 0.0 \\
Weighted average & 16.7 & 0.0 & 0.0 \\
Maximum rate & 60.0 & 0.0 & 0.0 \\
$\begin{array}{l}\text { Rwanda } \\
\text { Weighted average }\end{array}$ & 2.1 & 2.4 & 0.0 \\
$\begin{array}{l}\text { Maximum rate } \\
\text { Tanzania }\end{array}$ & 60.0 & 30.0 & 0.0 \\
Weighted average & 1.8 & 1.6 & 0.0 \\
$\begin{array}{l}\text { Maximum rate } \\
\text { Uganda }\end{array}$ & 25.0 & 50.0 & 0.0 \\
Weighted average & 3.3 & 1.1 & 0.0 \\
Maximum rate & 7.0 & 9.0 & 0.0 \\
\hline
\end{tabular}

Source: authors' calculations based on World Integrated Trade Solution (WITS) data.

The overall decline in tariffs in the EAC was strongest for capital goods, where the weighted average tariff dropped from almost 9 per cent in 2003 to about 4 per cent in 2014. Apart from those listed as sensitive items, capital goods imports are not protected. This encourages industrial production by reducing the costs of machinery and other capital inputs for producers.

Intermediate goods imported into the EAC still face a tariff rate of 10 per cent, however, which affects firms that rely on imported inputs. Due to limited local availability the majority of intermediates are imported into the EAC-in 2014 only 6 per cent (US\$1,594) of the EAC's imported intermediates were sourced from within the EAC, compared to 14 per cent for consumption goods. ${ }^{5}$ This indicates that RVCs are only emerging slowly. Imports of intermediates within the EAC are particularly weak in fuels and lubricants and in parts and accessories of capital goods and transport equipment. ${ }^{6}$

In 201457 per cent of EAC's imported intermediates from outside were industrial-related (industrial supplies, parts and accessories of capital goods, transport equipment, and other industrial), indicating limited value chains of industrial inputs. Some exceptions exist (see Figure 5). For example, 34 per cent of primary industrial supply products such as cement are sourced within the EAC. As expected, the least developed EAC partner states, Burundi and Rwanda, import larger shares of intermediate inputs from within the region and export fewer intermediates to the EAC. Kenya is the leading exporter of intermediates within the EAC (44 per cent) followed by Uganda (22 per cent) and Tanzania (21 per cent).

\footnotetext{
5 Authors' calculations using 2013 data for Kenya.

${ }^{6}$ With the exception of Burundi importing 100 per cent of its primary fuels and lubricants from the EAC.
} 
Figure 5: Intra-EAC imports of intermediate goods as a share of total imports of intermediate goods, by partner state

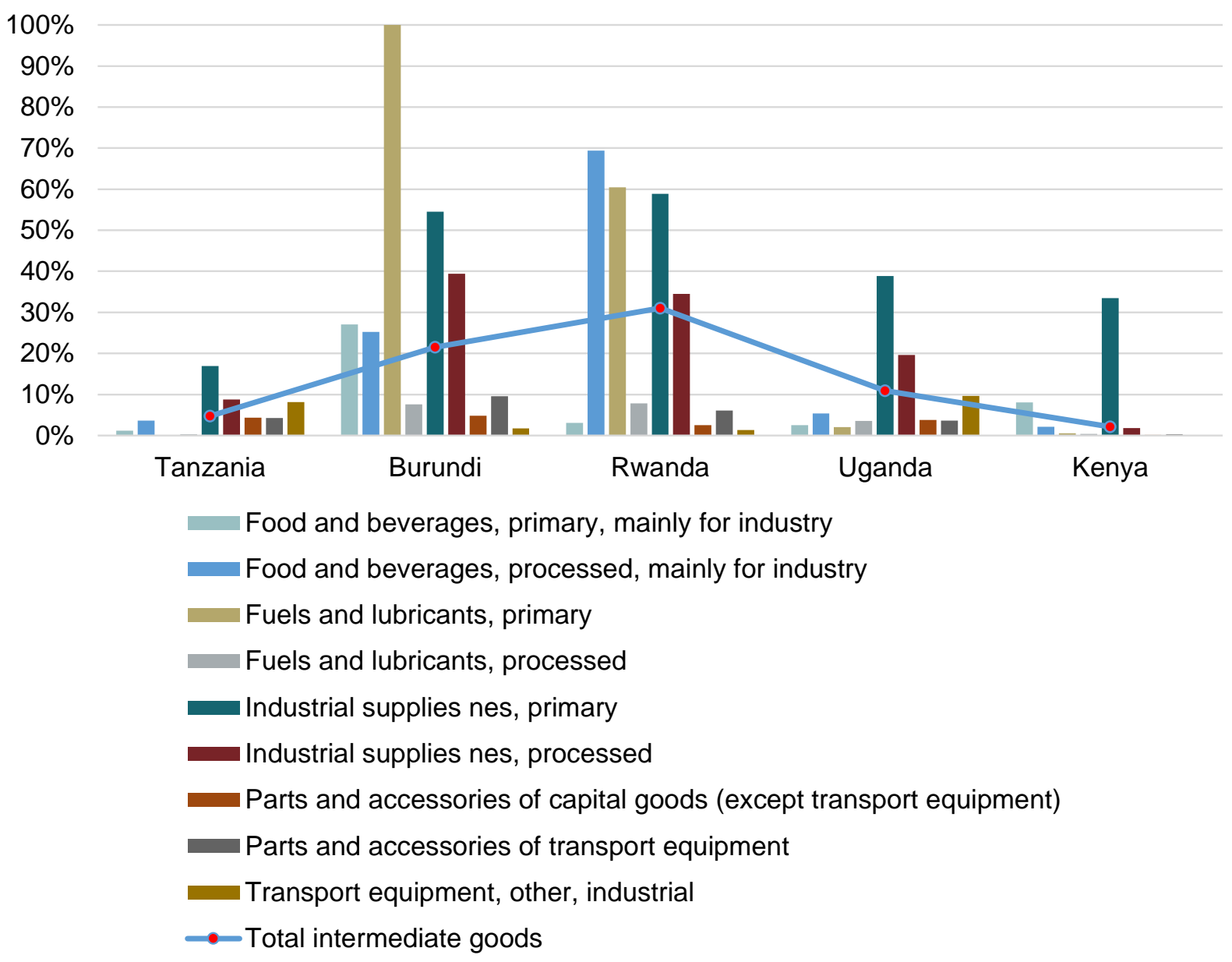

Note: nes $=$ not elsewhere specified.

Source: authors' calculations based on UN Comtrade data.

The protection imposed by EAC partner states on imported intermediate goods currently limits their use in production processes and possibilities for the export of transformed products. This constrains the development of smokestack-free industries such as agro-processing and textiles, which rely heavily on imported machinery and other inputs. A review of the CET structure is needed to ensure consistency with industrial frameworks and promote competitiveness based on comparative advantage. Frazer recently estimated that a 5 percentage point tariff reduction on inputs used by Rwandan exporters would result in a 5-10 per cent increase in their exports (Frazer 2012).

EAC partner states have in fact recently resolved to review existing CET rates and the basket of sensitive goods. Each partner state appointed an expert team to participate in negotiations from July 2016 to inform the finalization of a comprehensive CET review by December 2016 for implementation from July 2017 (EastAfrican 2016). This provides an opportunity to reduce the tariffs on imported intermediates. Conversely, tariffs on intermediates for which regional production already exists could be increased (e.g. steel and iron products), possibly through updating the sensitive items list. This would increase the protection provided for local producers, help to prevent premature de-industrialization and encourage intra-EAC trade in intermediates and the development of new RVCs. 
The classification of products under the three-band CET structure has caused concern among producers within the EAC, who argue that some items that are imported as finished products are actually used as inputs in industrial production. This reduces the competitiveness of manufacturers who are required to pay duty rates of 25 per cent as opposed to 0 or 10 per cent. For example, palm oil is imported as a finished product under the CET regime, but is used as a raw material in the manufacture of soap. Similarly, clinker is imported as a finished product but used as an intermediate input in the manufacture of cement. The CET review should therefore also consider updating the classification of products under the three-band structure to reflect the primary use of imports (EastAfrican 2016).

\subsection{Sensitive items}

The EAC allows a list of sensitive items to have higher tariff lines than the maximum CET rate of 25 per cent. Higher protection for these items was justified on the grounds of food security, poverty reduction, and the protection of vulnerable domestic producers. Reaching agreement on the classification of the 1.2 per cent of tariff lines defined as sensitive items was not easy. EAC partner states indicated that they wanted to protect subsidized exports (mainly agricultural products from industrial countries) and second-hand items from import competition (McIntyre 2005). The selection of sensitive tariff lines has been criticized for being influenced by vested interest groups with political influence in Kenya, Tanzania, and Uganda, without a prior in-depth analysis of economic and poverty implications.

Fifty-nine tariff lines are designated as EAC sensitive products, of which 31 are agricultural lines (at HS8 level). Table 5 shows the goods categorized as sensitive. The names of product categories are simplified for ease of reading. Fully detailed product names can be found in the link provided in the table source. Sugar is the most highly protected, with a tariff rate of 100 per cent for some types of sugar products. Rice is also heavily protected, with a 75 per cent tariff rate, followed by wheat, meslin flour, and dairy products at 60 per cent. 
Table 5: List of EAC tariffs for sensitive items

\begin{tabular}{ll}
\hline Items & Rate \\
\hline Cane or beet sugar and chemically pure sucrose, & 35 per cent for jaggery; 100 per cent or \\
in solid form & US $\$ 200 /$ metric ton (MT) for other, whichever is \\
& higher for industrial sugar and other types \\
Rice & 75 per cent or US $\$ 200 / \mathrm{MT}$, whichever is higher \\
Wheat and meslin flour & 60 per cent \\
Milk, cream, buttermilk, yoghurt, and most other & 60 per cent \\
dairy products & \\
Maize (corn) & 50 per cent \\
Cement & 55 per cent \\
Matches & 50 per cent \\
Various types of woven fabrics of cotton or & 50 per cent \\
synthetic staple fibres & \\
Tracksuits, ski-suits, and swimwear; other & 50 per cent \\
garments & \\
Bed linen, table linen, toilet linen, and kitchen linen & 50 per cent \\
Sacks and bags of a kind used for the packing of & From 35 per cent or US $\$ 0.20 / \mathrm{kg}$, whichever is \\
goods & higher, to 45 per cent or $45 \$$ per bag, \\
Stoppers, caps, and lids; capsules for bottles, & whichever is higher \\
bungs, seals, and other packing accessories & 40 per cent \\
Primary cells and batteries & 35 per cent \\
Tobacco products & 35 per cent \\
Wheat and meslin & 35 per cent \\
\hline
\end{tabular}

Source: EAC sensitive items list (http://tradehelpdesk.eac.int/documents/Sensitive_List.pdf).

Data show that the EAC does not have the supply capacity needed to fulfil demand for the majority of sensitive items (see Table 6). In 2012, over 90 per cent of EAC demand was met by imports from the rest of the world for 65 per cent of the sensitive tariff headings. These include important consumer and industrial products such as woven fabrics of cotton and synthetic staple fibres, wheat and meslin, sugar, linens, and primary cells and batteries. The high CET rates attached to these products negatively impact consumer welfare and raise the costs of industrial development. EAC partner states imported about US $\$ 217$ million worth of sugar from outside the region in 2012, at tariff rates as high as 100 per cent. This seems to show that such high tariffs, while protecting nascent local industries, may be excessive. Taking the example of sugar, high tariffs increase costs for consumers, but also constrain the development of agro-processing smokestackfree industries that rely on sugar as a key production input (e.g., soft drinks, biscuits, and candy). 
Table 6: Intra-EAC import share of total EAC imports of sensitive items by tariff heading (percentage)

\begin{tabular}{|c|c|c|c|c|c|c|c|c|c|c|}
\hline & 2003 & 2004 & 2005 & 2006 & 2007 & 2008 & 2009 & 2010 & 2011 & 2012 \\
\hline Milk and cream, not concentrated & 51.2 & 4.8 & 52.9 & 41.2 & 38.6 & 54.9 & 77.4 & 84.8 & 70.5 & 95.6 \\
\hline Milk and cream, concentrated & 11.3 & 3.6 & 4.5 & 34.9 & 42.7 & 37.2 & 28.5 & 41.4 & 13.6 & 36.1 \\
\hline Other milk products & 23.1 & 34.4 & 47.0 & 54.9 & 34.9 & 56.2 & 46.9 & 50.9 & 19.8 & 45.5 \\
\hline Wheat and meslin & 2.1 & 2.0 & 2.2 & 0.4 & 0.4 & 0.1 & 0.3 & 0.3 & 0.4 & 0.3 \\
\hline Maize (corn) & 27.2 & 4.4 & 19.1 & 9.8 & 87.1 & 9.5 & 3.1 & 18.1 & 29.0 & 41.3 \\
\hline Wheat or meslin flour & 60.2 & 0.2 & 71.4 & 79.6 & 5.0 & 10.9 & 9.4 & 7.6 & 2.8 & 0.7 \\
\hline Sugar & 1.2 & 0.0 & 5.6 & 3.4 & 4.1 & 2.1 & 4.1 & 2.7 & 6.4 & 3.9 \\
\hline Cigars, cheroots, cigarillos, and cigarettes & 74.0 & 37.5 & 29.6 & 60.3 & 76.7 & 83.8 & 84.9 & 77.3 & 92.5 & 85.5 \\
\hline Other manufactured tobacco & 46.0 & 1.3 & 55.9 & 31.7 & 0.2 & 0.3 & 2.7 & 0.0 & 0.1 & 0.0 \\
\hline Cement & 52.3 & 46.6 & 54.9 & 47.7 & 31.1 & 35.0 & 47.7 & 32.1 & 61.8 & 35.5 \\
\hline Matches & 2.4 & 0.0 & 0.1 & 2.8 & 0.2 & 0.3 & 6.7 & 4.1 & 4.1 & 4.2 \\
\hline Woven fabrics 5208 & 0.1 & 6.6 & 1.3 & 3.4 & 1.8 & 1.0 & 1.2 & 1.2 & 1.3 & 1.1 \\
\hline Woven fabrics 5209 & 7.0 & 0.7 & 0.0 & 0.5 & 0.7 & 0.9 & 2.6 & 3.4 & 34.5 & 0.1 \\
\hline Woven fabrics 5211 & 0.0 & 1.0 & 1.9 & 0.6 & 9.6 & 11.7 & 11.6 & 6.7 & 17.6 & 0.1 \\
\hline Woven fabrics 5212 & 0.4 & 0.0 & 1.4 & 1.1 & 0.4 & 0.2 & 0.3 & 0.5 & 4.2 & 1.8 \\
\hline Woven fabrics 5513 & 4.8 & 7.5 & 2.4 & 1.9 & 2.6 & 2.4 & 2.1 & 2.7 & 12.0 & 0.6 \\
\hline Woven fabrics 5514 & 2.0 & 2.6 & 2.7 & 1.4 & 1.1 & 2.4 & 4.2 & 3.5 & 7.5 & 4.2 \\
\hline Garments & 1.8 & 3.2 & 14.0 & 2.5 & 4.4 & 2.7 & 2.6 & 4.0 & 4.7 & 3.7 \\
\hline Linens & 1.1 & 3.2 & 3.3 & 2.2 & 1.8 & 3.6 & 2.4 & 1.2 & 17.2 & 1.8 \\
\hline Sacks and bags & 45.7 & 21.0 & 18.4 & 24.5 & 29.8 & 25.5 & 17.9 & 20.0 & 26.5 & 23.2 \\
\hline Worn clothing & 0.5 & 1.7 & 1.5 & 1.7 & 0.5 & 0.7 & 0.9 & 1.1 & 1.2 & 0.4 \\
\hline Packaging accessories & 40.3 & 30.6 & 25.4 & 29.3 & 21.2 & 36.9 & 40.4 & 40.1 & 78.6 & 43.8 \\
\hline Primary cells and batteries & 2.8 & 2.0 & 2.4 & 3.5 & 5.2 & 2.3 & 3.0 & 1.7 & 2.2 & 0.4 \\
\hline
\end{tabular}

Note: for details on the breakdown of woven fabrics, see the sensitive items list at: http://tradehelpdesk.eac.int/documents/Sensitive_List.pdf.

Source: authors' calculations based on WITS data.

Intra-EAC trade in sensitive items is relatively high for a limited number of products. These include dairy products, maize, cigars and cigarettes, cement, sacks and bags, and packaging accessories. Although these industries were already relatively strong before the CET, the high sensitive item tariff rates have supported their expansion. For example, 85 per cent of the EAC's imports of cigars and cigarettes originated from the region (largely Kenya) in 2012, compared with 30 per cent in 2005.

Some industries, such as steel and iron, have been competitive without sensitive item status, both in the EAC and internationally. The EAC exported about US $\$ 73$ million of coated iron and nonalloy steel flat-rolled products within the region in 2014, and about US $\$ 59$ million to the rest of the world-protection of these products ranges from 0 to only 25 per cent. The boom in construction in the region is driving the steel and iron industry. In Uganda and Kenya, where ore deposits have been discovered, governments are encouraging investments in iron ore (Construction Review 2013). The EAC Secretariat has banned exports of scrap metal, which has led to more accessible and cheaper inputs for steel processors in the region. This highlights that competitive industries can be achieved through other means than protective tariffs, and points to the need for supportive industrial policies and interventions to address supply-side constraints (African Review 2012).

Table 7 reports the exports of sensitive products for each EAC partner state in 2014. Uganda and Tanzania export the highest number and greatest value of sensitive products. Tobacco, maize, and 
sugar are the most widely exported sensitive products in the region, with total EAC exports at US $\$ 500$ million, US $\$ 140$ million, and US $\$ 130$ million, respectively. The sensitive product share in the value of exports is 12 per cent for Tanzania, 11 per cent for Uganda, 6 per cent for Rwanda and Burundi, and only 2 per cent for Kenya. The dairy industry, on which the paper's case study focuses, has benefited from sensitive item tariff protection.

Table 7: 2014 EAC exports of sensitive products, by partner state (US\$ thousands)

\begin{tabular}{|c|c|c|c|c|c|c|}
\hline & Tanzania & Kenya & Uganda & Rwanda & Burundi & EAC \\
\hline $\begin{array}{l}\text { Cane or beet sugar and chemically } \\
\text { pure sucrose, in solid form }\end{array}$ & 61,374 & 486 & 64,556 & 3,023 & - & 129,439 \\
\hline Rice & 19,193 & 218 & 28,688 & 14,897 & - & 62,996 \\
\hline Wheat or meslin flour & 16,129 & 84 & 29,250 & 20,387 & 4,626 & 70,476 \\
\hline $\begin{array}{l}\text { Milk, cream, buttermilk, yoghurt, and } \\
\text { most other dairy products }\end{array}$ & 152 & 13,194 & 24,553 & 3,080 & 19 & 40,998 \\
\hline Maize (corn) & 107,400 & 4,522 & 28,977 & 181 & - & 141,080 \\
\hline $\begin{array}{l}\text { Articles of cement, concrete, or } \\
\text { artificial stone }\end{array}$ & 309 & 735 & 252 & 372 & - & 1,668 \\
\hline $\begin{array}{l}\text { Matches, other than pyrotechnic } \\
\text { articles of heading } 36.04^{a}\end{array}$ & 544 & 368 & 1,906 & 1 & - & 2,819 \\
\hline $\begin{array}{l}\text { Various types of woven fabrics of } \\
\text { cotton or synthetics }\end{array}$ & 7,176 & 1,175 & 711 & 862 & 7 & 9,931 \\
\hline $\begin{array}{l}\text { Bed linen, table linen, toilet linen, and } \\
\text { kitchen linen }\end{array}$ & 121 & 728 & 366 & 15 & - & 1,230 \\
\hline $\begin{array}{l}\text { Tracksuits, ski-suits, and swimwear; } \\
\text { other garments }\end{array}$ & 4 & 5 & 2 & - & - & 11 \\
\hline $\begin{array}{l}\text { Sacks and bags of a kind used for } \\
\text { the packing of goods }\end{array}$ & 22,532 & 3,386 & 2,931 & 537 & 10 & 29,396 \\
\hline Primary cells and primary batteries & 34 & 963 & 1,481 & 709 & 1 & 3,188 \\
\hline $\begin{array}{l}\text { Tobacco and manufactured tobacco } \\
\text { substitutes }\end{array}$ & 322,943 & 106,531 & 66,018 & 584 & 3,255 & 499,331 \\
\hline
\end{tabular}

Note: a this refers to matches other than fireworks, signalling flares, rain rockets, fog signals, and other pyrotechnic articles.

Source: ECA analysis of International Trade Centre data.

The benefits of high protection of sensitive items are unequally distributed among partner states (see Figure 6). Thirty per cent and 23 per cent of intra-EAC exports from Tanzania and Uganda respectively are of sensitive products. The other three partner states export a much lower share of sensitive products within the region. This unequal distribution, which penalizes Burundi and Rwanda, reflects their delayed entry into the CU, by which time the sensitive items list had already been drawn up. 
Figure 6: Exports of sensitive products within the EAC (percentage of total exports)

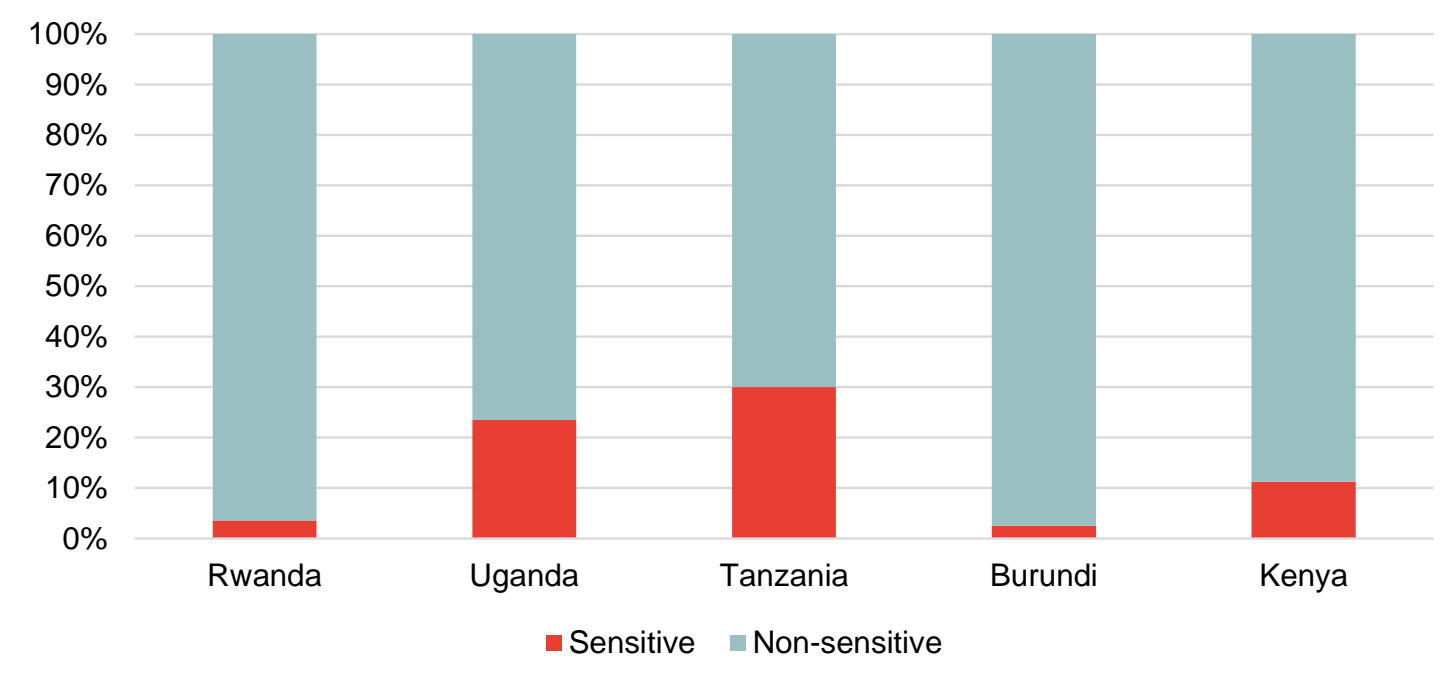

Source: ECA calculations based on UNCTADstat.

Table 8 provides export shares for sensitive products that appear within the top five exports of EAC partner states. These items represent a large share of the goods traded within the region, most notably cement, maize, textiles, rice, and dairy. For example, in 2014 rice contributed 13 per cent of Tanzania's exports to Uganda and construction materials including cement contributed 12 per cent of Kenya's exports to Uganda. Other sensitive items are, however, much less widely traded within the region due to inadequate supply. The EAC also relies significantly on imports from the rest of the world for some of the sensitive items that are widely traded within the region. For example, imports of sugar into the EAC more than doubled between 2005 and 2012, even with a 100 per cent tariff.

Table 8: Trade in sensitive products within the EAC considering only the top five exports for each trading partner (share of a partner states exports to the trading partner), 2014

\begin{tabular}{|c|c|c|c|c|c|}
\hline Sensitive product & Rwanda & Kenya & Uganda & Tanzania & Burundi \\
\hline Rice & Tanzania (2\%) & & & $\begin{array}{l}\text { Uganda (13\%) } \\
\text { Burundi }(6 \%)\end{array}$ & \\
\hline $\begin{array}{l}\text { Construction materials } \\
\text { including cement }\end{array}$ & Burundi (7\%) & Uganda (12\%) & $\begin{array}{c}\text { Rwanda } \\
(29 \%) \\
\text { Burundi }(12 \%)\end{array}$ & $\begin{array}{c}\text { Rwanda } \\
\text { (11\%) Burundi } \\
(24 \%)\end{array}$ & \\
\hline Sugar & & & Rwanda (3\%) & & \\
\hline Maize & & & Tanzania (8\%) & Kenya (21\%) & \\
\hline Tobacco (manufactured) & & $\begin{array}{l}\text { Rwanda (2\%) } \\
\text { Uganda (2\%) }\end{array}$ & & & $\begin{array}{c}\text { Tanzania } \\
(14 \%)\end{array}$ \\
\hline $\begin{array}{l}\text { Milk, cream, and milk } \\
\text { products }\end{array}$ & & & Kenya $(7 \%)$ & & \\
\hline Textiles & & & & $\begin{array}{c}\text { Kenya }(21 \%) \\
\text { Uganda }(14 \%) \\
\text { Burundi }(8 \%)\end{array}$ & Kenya (1\%) \\
\hline
\end{tabular}

Source: ECA analysis of UNCTAD data. Classification of products available at: http://unstats.un.org/unsd/cr/registry/regcs.asp?Cl=14\&Lg=1\&Co=658

The total value of sensitive products imported from the rest of the world grew from approximately US $\$ 700$ million in 2005 to US $\$ 1$ billion in 2012 . The products that recorded the highest level of imports from outside the EAC were wheat and meslin (US\$221 million), sugar (US\$217 million), cement (US\$113 million), and used clothing (US\$161 million). Given the large tariff costs this imposes on importers, the proposed review of the CET structure and sensitive items list is very 
much needed to ensure that the $\mathrm{CU}$ remains consistent with EAC consumption and industrial demands, as well as with the region's productive capabilities. CET revenues from sensitive products account for only 4.6 per cent of total CET revenue for all partner states (Government of Uganda n.d.) - reducing tariffs on certain sensitive tariff lines therefore should not hit CET revenue significantly, but would instead likely bolster other taxes linked to the size of the economic base. An updated sensitive items list would also ensure a more balanced list reflective of the priorities of all EAC partner states, including Burundi and Rwanda, the late joiners to the CU.

Since 2005, EAC partner states have continually made amendments to the CET and the 2004 Customs Management Act, including general exemptions on various tariff headings, tariff rates, stay of application of the CET, and duty remission. Such discretionary action erodes the CET (Kitenga 2012). The June 2016 EAC Gazette published a 46-page new round of stay of applications and duty remissions (EAC Gazette 2016). ${ }^{7}$ This long list suggests that the economic and welfare impacts of the CET were not fully considered when designing the schedule of sensitive item tariff lines. The productive capacity of partner states to supply the majority of sensitive items was inadequate when the CU started. High tariff rates have therefore reduced the competitiveness of EAC firms that rely on imported inputs, and have raised consumers' costs.

The continual granting of ad-hoc annual remissions should not serve as a substitute for a comprehensive CET review-remissions create unpredictability, distort the value chain planning of producers within the region, and create uncertainties for third parties with trade and investment interests in the EAC. In order to be effective, the proposed EAC CET review must be informed by evidence-based studies that consider partner states' industrial development needs and existing supply capacities. In particular, the review should consider which sensitive goods local industries need to import as inputs for production. The CET structure could be reviewed every five yearsthis would still provide a relatively predictable regime that can also reflect changing development needs and emerging regional production capabilities.

Tariff rates should be reduced for key industrial inputs (e.g. sugar and woven fabric) and basic necessity consumption goods (e.g. wheat) with limited regional availability. High sensitive item tariff rates on dairy, maize, cement, cigars and cigarettes, sacks and bags, and packing accessories should be maintained-EAC production in these areas is significant and current rates can support further growth and intra-EAC trade in these products.

To support the construction sector, the East African Council of Ministers reduced the duty on cement imported into the EAC from 35 per cent to 25 per cent in 2015, temporarily removing cement from the sensitive items list. However, cement manufacturers in the region lodged a petition to reverse this decision (EastAfrican 2015). It is important that protection of the EAC's cement industry continues under the sensitive items schedule for a limited period of time, so that EAC's producers are able to develop the capacities over time to compete more effectively at an international level. Without this level of protection, lower-cost cement manufacturers in Asia and elsewhere will be the main beneficiaries of the growing demand for cement by EAC partner states, despite the significant production capacities and RVCs in the region. However, as operational costs fall—particularly high energy costs — protection should be reduced. Some cement tariff lines are only sourced from outside the region-these tariff lines could be treated differently and immediately attract a lower tariff rate.

7 This included Rwanda's stay of application of the CET on wheat and application of a duty rate of 0 per cent instead of 35 per cent for one year, and duty remission for Kenya on raw sugar for manufacture of sugar for industrial use at a duty rate of 0 per cent for one year, among many others. 


\subsection{Beyond the $\mathrm{CU}$}

Although the CU has helped to increase the value of intra-EAC trade, the share of intra-EAC trade in total EAC trade remains low. One of the main reasons is the high level of border barriers in the region, including significant transport costs for landlocked EAC partner states and high ad valorem equivalents for NTBs (see Section 2.1).

In order to increase trade competitiveness and maximize the benefits of the EAC free trade area, partner states have an ambitious agenda for the elimination of remaining NTBs. The EAC Secretariat publishes a quarterly report of NTBs in the region. ${ }^{8}$ In December 2014, the report classified 18 NTBs as 'unresolved', 4 as 'new', and 78 as 'resolved'. The vast majority of resolved as well as unresolved NTBs were 'procedural problems' (EAC Secretariat 2014). Recent measures taken to reduce non-tariff costs and other impediments to regional trade include the implementation of: One Stop Border Posts; the Single East African Tourist Visa; joint regional transportation and energy infrastructure projects; and the East African Payments System.

High costs of trading services also constrain trade in goods within the region as services are key inputs into the production and distribution of goods for export. According to World Bank Enterprise Survey data, services account for 22.2 per cent of total input costs in EAC countries (Hoekman and Shepherd 2016). Although total trade in services has increased significantly since the beginning of the millennium (see Figure 7), opportunities for trade in services within the region still remain underexploited. This reflects high services trade restrictions within the EAC. All partner states apart from Burundi rank in the top (more restrictive) half of the World Bank's 104country Services Trade Restrictions Index. Partner states have undertaken liberalization of trade in services through the establishment of the $\mathrm{CM}$, and trade in services has been included in EAC National Development Plans, National Trade Policies, and CM Implementation Plans. Liberalization of trade in services has, however, been slow.

Figure 7: Total trade in services (exports and imports) in East Africa

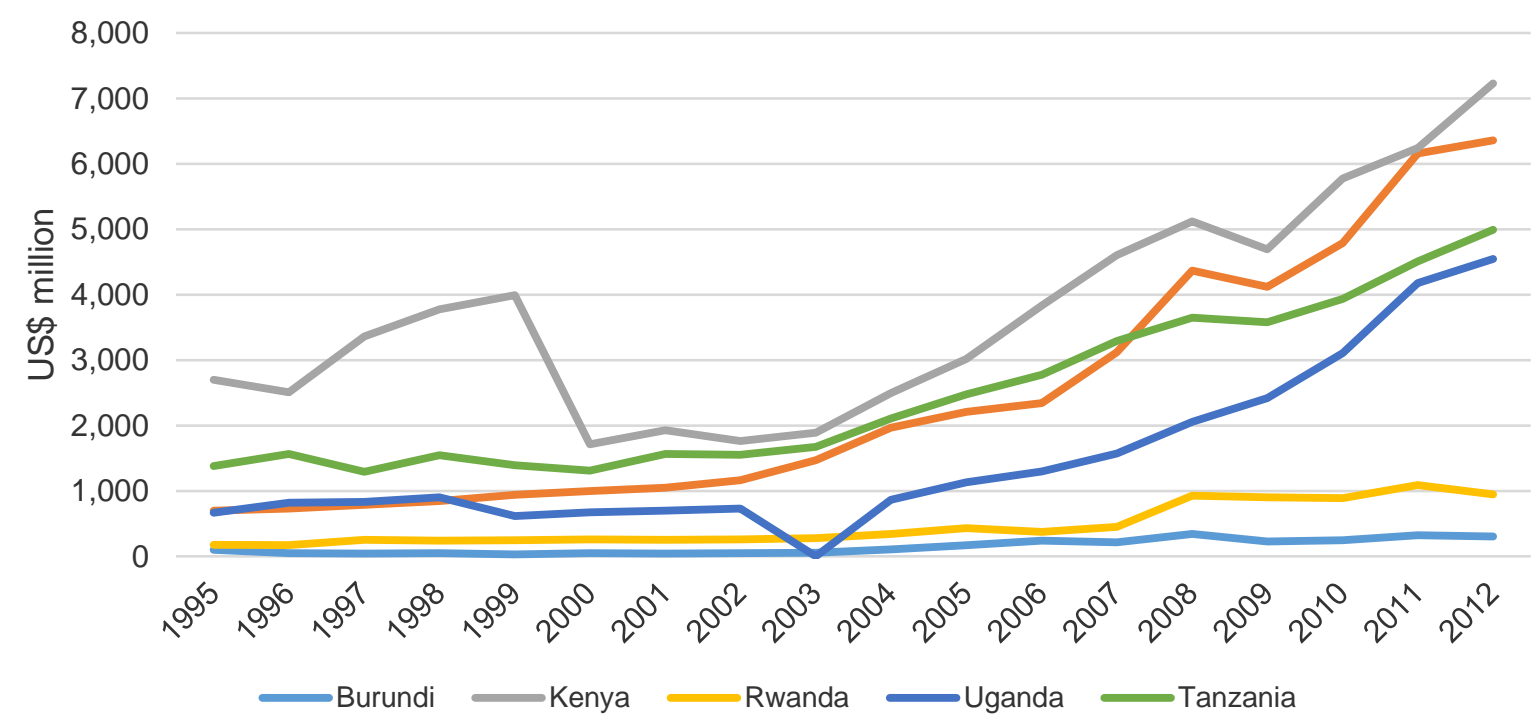

Note: US dollars at current prices and current exchange rates.

Source: UNCTADstat.

8 The EAC defines NTBs as 'quantitative restrictions and specific limitations that act as obstacles to trade'. 
This slow progress in trade in services liberalization reflects a number of challenges, including poor coordination between institutions, that are relevant to the reforms on trade in services: a lack of adequate policy and regulatory frameworks for opening some service sectors; and a lack of adequate statistical data on trade in services to guide the agenda (ILEAP 2012). The EAC CM Scorecard was launched in 2014 to encourage peer learning and improve compliance with commitments under the CM Protocol. It covers four services sectors: professional services, road transport, distribution, and telecommunications legislation. The 2014 review studied over 500 key sectoral laws and regulations of EAC partner states and identified at least 63 measures inconsistent with commitments to liberalize services trade within the EAC, 73 per cent of which were accounted for by professional services. About three-quarters of the identified measures discriminated against service suppliers of the EAC partner states; the remainder involved preferences for service suppliers outside of the EAC (World Bank et al. 2014).

Violations identified through the Scorecard provide opportunities for reforms focused on aligning partner states' legislations with the trade in services obligations under the CM Protocol. A recent study by Hoekman and Shepherd (2015) shows that services policies and sectoral competitiveness are important determinants of downstream productivity and exports in goods sectors in the EAC. The authors estimate that if the EAC were to implement reforms that would lower the average level of services trade restrictions to that of Ghana (the African country with the fewest services trade barriers), exports of EAC countries would increase substantially-4.4 per cent, 18.6 per cent, 13.0 per cent, 19.8 per cent, and 23.1 per cent in Burundi, Kenya, Rwanda, Tanzania, and Uganda, respectively. Reforms in retail distribution and transport have particularly high payoffs. These effects result from the positive relationship between services productivity and manufacturing productivity, which in turn contributes to higher exports (Hoekman and Shepherd 2015).

\section{Structural transformation in the EAC}

\subsection{Sectoral analysis of structural change}

The composition of output in the EAC changed markedly over the last two decades (see Figure 8). The region registered a significant decline in the GDP shares of agriculture, hunting, forestry, and fishing from an unweighted average of 38.9 per cent in 1995 to 32.7 per cent in 2014.

The majority of the EAC's decline in agriculture's share of GDP, however, took place in the 10 years prior to the introduction of the CU in 2005. Rwanda was the only country that saw a significant reduction in the share of agriculture, hunting, forestry, and fishing following the CU, from 41.3 per cent in 2005 to 35.0 per cent in 2014. As shown in Figure 8, manufacturing shares remained fairly constant across the EAC following 2005. At the same time, all countries saw growing shares for construction driven by large public investment programmes. Services' contribution to GDP increased marginally after the CU. 
Agriculture, hunting, forestry and fishing

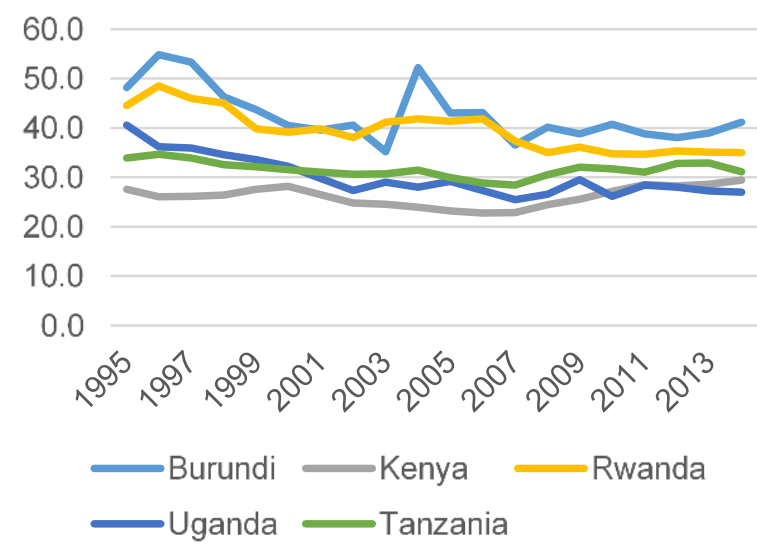

Mining and utilities

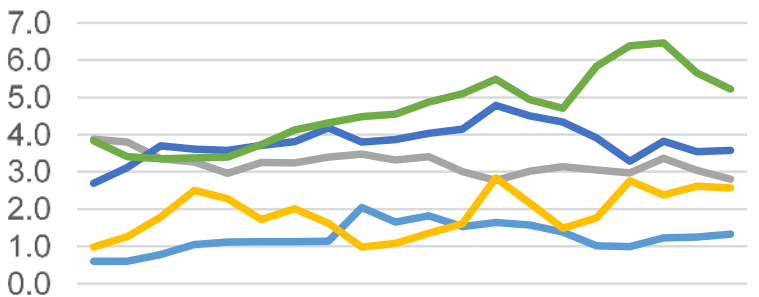

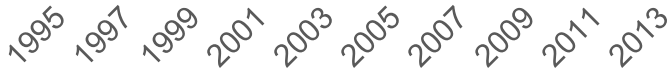

$$
\begin{aligned}
& \text { - Burundi }- \text { Kenya } \text { Uganda } \text { Tanzanda }
\end{aligned}
$$

Wholesale, retail trade, restaurants and hotels

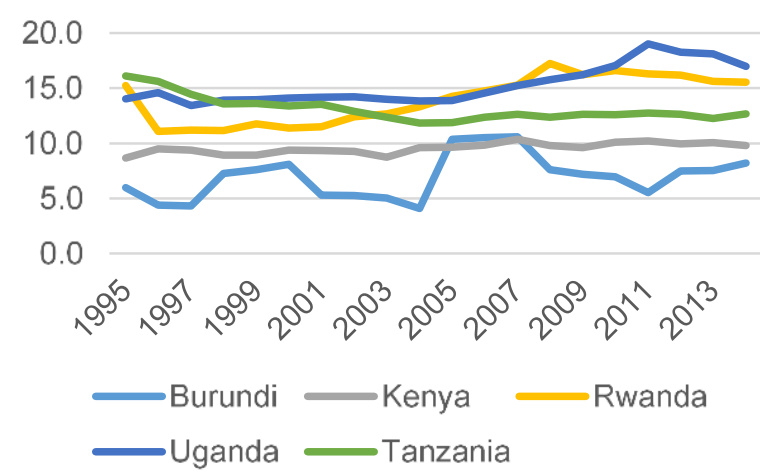

Manufacturing

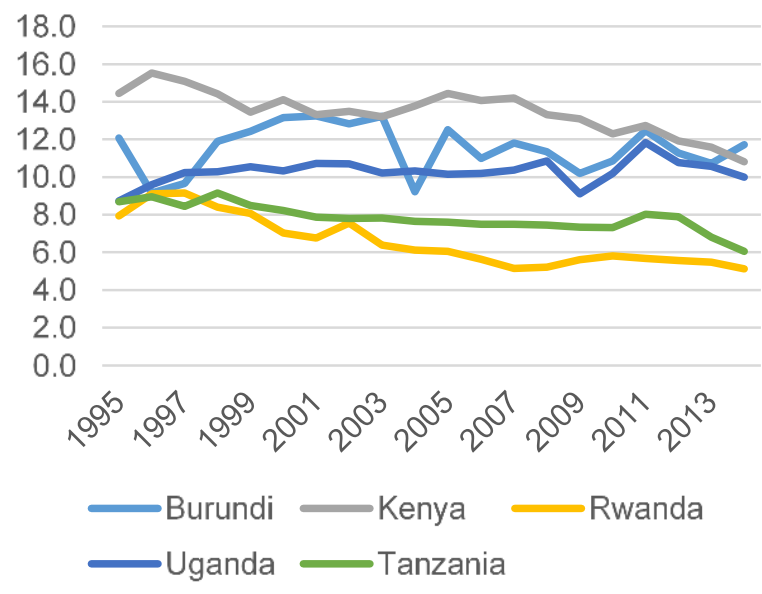

Construction

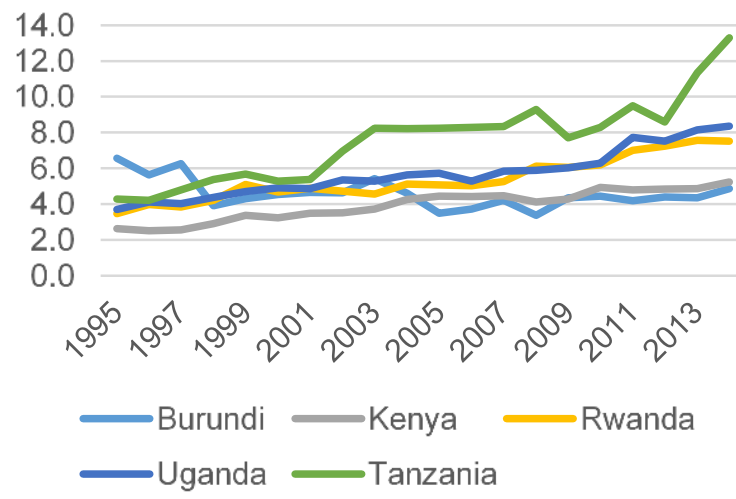

\section{Transport, storage and communications}

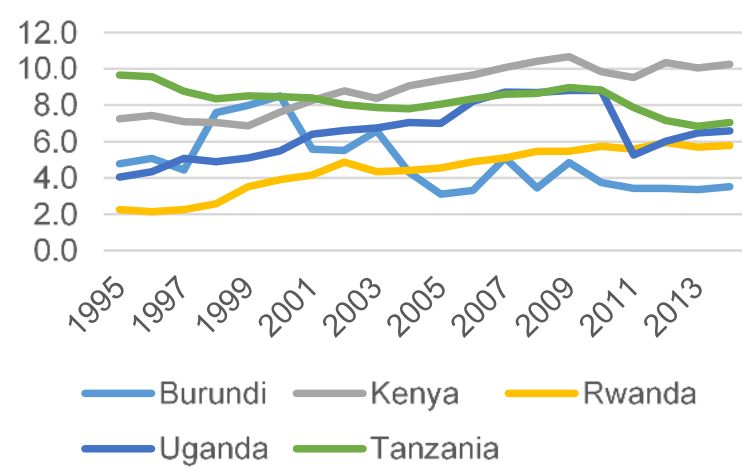

Source: authors' calculations based on UNCTADstat.

The minimal change in GDP compositions following 2005 indicates limited structural change at the sectoral level over the last decade. Structural change is, however, a long-term process that requires fundamental changes to the supply side of the economy. The significant growth of the construction sector in the EAC, from an unweighted average of 5.4 per cent in 2005 to 7.9 per 
cent in 2014, reflects an expansion of public investment and infrastructure programmes to enhance connectivity and productive capacity. This should provide an impetus to positive structural change in the medium term. Moreover, implementation of the CU has been gradual, with supportive interventions such as implementation of the $\mathrm{CM}$ and trade facilitation measures moving at a slower pace. Fast-tracking such complementary regional integration efforts would maximize positive impacts of the EAC free trade area on production structures. The significant structural change that had already taken place across partner states has also left less scope for additional immediate restructuring following the CU.

Overall, industrial activity in the EAC remains lacking. Manufacturing in the region still faces massive obstacles such as large overheads, expensive borrowing, high costs for imported inputs, skill deficiencies, and infrastructure gaps such as energy and transport. Regional cooperation should be strengthened to ensure effective policy coordination towards eliminating the binding constraints to firm upgrading and the creation of new productive industries.

\subsection{Industry analysis of structural change}

Over the last decade, EAC partner states have seen a number of new industries grow and emergemost notably agro-processing, tourism, cement production, pharmaceuticals, and textiles. Many of these industries are smokestack-free and are increasingly associated with greater value addition, processing, and innovation. Below, we provide some examples of important smokestack-free industries in the region.

\section{Agro-processing}

Given the importance of agriculture to output and employment in the EAC, it makes sense to add value to the region's agricultural produce. Smokestack-free agro-processing is indeed the lead manufacturing industry in the EAC. Table 9 highlights important agro-processed products that have recorded significant growth in Kenya, Uganda, Rwanda, and Tanzania in recent years.

Table 9: Important agro-processed products produced in EAC partner states

\begin{tabular}{ll}
\hline & Agro-processed products \\
\hline Uganda & $\begin{array}{l}\text { Edible oils and fats production, dairy production, grain milling, bakery production, sugar } \\
\text { processing and coffee processing, fruit and vegetable juices, beer production (UBOS 2015) }\end{array}$ \\
Kenya & $\begin{array}{l}\text { Vegetable and animal oils and fats, dairy products, starches and starch products, prepared } \\
\text { animal feeds, sugar, cocoa, chocolate and confectionary sugar, tobacco, cut flowers (KNBS } \\
\text { 2015) }\end{array}$ \\
Rwanda & $\begin{array}{l}\text { Milk production, beer production, fish and honey production, bakery products, manufacture of } \\
\text { sugar, processing of meats, fruit and vegetables (NISR 2015) }\end{array}$ \\
Tanzania & Biscuits, bottled beer, tobacco products, instant coffee, sugar, milk products (NBS 2014)
\end{tabular}

Source: statistical abstracts of respective partner state (sources noted in the table).

Textiles

Although the EAC still largely sources its textiles from outside the region, the production of textiles in Kenya, Tanzania, Uganda, and Rwanda has increased in recent years. All EAC countries, excluding Burundi, which lost its access to the African Growth and Opportunity Act (AGOA) on 1 January 2016, qualify to export textile products free of duty to the United States (US). This has helped to attract investors into the industry. In 2013, apparel exports from Tanzania, Uganda, Kenya, and Ethiopia totalled US\$337 million. 
Tanzania's textile industry has performed particularly well. It is the second largest employer in Tanzania's manufacturing industry. In 2014, 16,692 persons were employed in the manufacture of textiles at establishments with 10 or more workers-this is almost 13 per cent of the total number of people engaged in manufacturing establishments. The gross output of these textiles manufacturing establishments increased from TZS235,782 in 2011 to TZS272,947 in 2014 (NBS 2014). Tanzania is the second largest exporter of textiles in the EAC after Kenya. The country has around 22 textile factories. In 2014, textiles represented 16 per cent, 6 per cent, and 3 per cent of Tanzania's exports to the EAC, the rest of Africa, and the rest of the world, respectively. ${ }^{9}$ Tanzania's exports of textiles reached approximately US\$283 million in 2013 compared to only US\$51 million in 2000 .

The government of Tanzania has actively supported the textile industry and highlighted the performance of the industry as crucial to achieving middle-income status by 2025 . Tanzania aims to upgrade textile production to higher value-added cotton products for export, build the right supporting institutions, and improve the policy and business environment to tackle constraints in the industry.

The proposed EAC industrialization policy is expected to restrict imports of used clothes and shoes to protect the textiles manufacturing sector in the region. South Africa, which has such a ban in place, has a substantial textile industry. The majority of woven fabrics and garments are, however, currently imported from outside the EAC, despite CET protection of 50 per cent on the sensitive item list. This suggests the need to further boost regional supply capacities in textiles before introducing such a ban, in order to avoid ending up with cheap clothes smuggled into the region and EAC governments losing tariff revenue levied on used clothes imports—currently 35 per cent on the sensitive items list (The Economist 2016).

\section{Tourism}

Tourism is emerging as an important sector in Kenya, Tanzania, Uganda, and Rwanda. For example, Kenya received 1,143,722 holiday and business visitors in 2014 and parks and game reserves had 2,164,625 visitors (KNBS 2015). International arrivals to Uganda increased from about 1.3 million in 2010 to 1.7 million in 2014, whereas arrivals from the EAC increased from 550,000 to 807,000 (UBOS 2015). The sector is expected to receive an additional boost from the recently introduced Single EAC Tourist Visa.

Given the obstacles to developing competitive manufacturing in Rwanda, the government is targeting services subsectors for growth, including tourism. The tourism sector has been the main foreign exchange earner since 2007. In 2013, exports of travel were 77 per cent of commercial services exports and the Rwandan Tourism Board reported that the country had received 1,137,000 visitors, generating US $\$ 294$ million, up from just US $\$ 62$ million in $2000 .{ }^{10}$ Tourism receipts were 29 per cent of total exports in $2013,{ }^{11}$ and are expected to grow at a compound annual rate of 25 per cent until $2017 .{ }^{12}$

\footnotetext{
9 These figures were computed by the authors using UNCTAD data.

10 The figures were sourced from

www.rwandatourism.com/index.php/destinations-and-activities/nyungwe-national-park/96-media-centre/pressreleases.

11 This figure is computed from World Bank data.

12 This projection is from Rwanda Economic Development and Poverty Reduction Strategy 2013 targets.
} 
Although gorilla tourism remains one of Rwanda's main tourism marketing points, the government is now also trying to diversify the tourism products on offer. Thanks in part to improved infrastructure and telecommunication services, Rwanda is becoming increasingly attractive for Conference Tourism. In 2014 the country hosted both the African Development Bank meetings and the World Export Development Forum, among other events. The development of a competitive aviation sector is part of the government's strategy to develop the tourism sector (Republic of Rwanda 2013).

\section{$5 \quad$ Smokestack-free case study: the dairy industry in Uganda ${ }^{13}$}

\subsection{Background}

The dairy industry in Uganda provides an interesting case study of how existing productive knowledge in agriculture can be used to produce more sophisticated and higher value-added products to serve the domestic and regional markets.

As shown in Table 10, dairy is an important economic activity across East Africa, which is now the leading milk-producing region in Africa, representing 68 per cent of the continent's milk output (Bingi and Tondel 2015). The large EAC market and the existing high levels of dairy production in the region has also attracted the attention of private international players in the industry, many of which are facing weak growth in Europe and China-for example, Nestlé and Danone Dairy investments in Kenya.

Table 10: Dairy sector indicators in East Africa

\begin{tabular}{lccccccc}
\hline & $\begin{array}{c}\text { Milk } \\
\text { (million } \\
\text { tonnes) } \\
2011\end{array}$ & $\begin{array}{c}\text { Milk } \\
\text { (percentage } \\
\text { change } \\
2000-11)\end{array}$ & $\begin{array}{c}\text { Butter } \\
\text { (thousand } \\
\text { tonnes) }\end{array}$ & $\begin{array}{c}\text { Cheese } \\
\text { (thousand } \\
\text { tonnes) }\end{array}$ & $\begin{array}{c}\text { Smallholders } \\
\text { dairy farmers } \\
\text { (million) }\end{array}$ & $\begin{array}{c}\text { Percentage } \\
\text { share of } \\
\text { agricultural } \\
\text { GDP }\end{array}$ & $\begin{array}{c}\text { Percentage } \\
\text { share of } \\
\text { GDP }\end{array}$ \\
\hline Kenya & 4.3 & 5.5 & 14.7 & 0.3 & 2 & 50 & 3 \\
Rwanda & 0.2 & 5.3 & 0.7 & $\mathrm{n} / \mathrm{a}$ & 0.1 & 15 & 6 \\
Tanzania & 1.8 & 7.8 & 31.5 & 13.0 & $\mathrm{n} / \mathrm{a}$ & $\mathrm{n} / \mathrm{a}$ & 1.8 \\
Uganda & 1.2 & 8.0 & $\mathrm{n} / \mathrm{a}$ & $\mathrm{n} / \mathrm{a}$ & 0.7 & 50 & 8 \\
\hline
\end{tabular}

Sources: Bingi and Tondel 2015.

EAC exports of dairy products (milk, cream, and milk products) to both the region and the world increased significantly following the establishment of the CU in 2005 (Figure 9). The value of intraEAC exports of dairy products jumped from US $\$ 281,445$ in 2005 to US $\$ 18.3$ million in 2014, a 6,402 per cent increase. The share of intra-EAC exports in total EAC exports of dairy products increased from only 5 per cent to 39 per cent over the same period.

13 This case study is informed by the authors' findings from a field visit to Uganda to meet with key players in the dairy sector in July 2016. The meetings were geared towards hearing views on the factors contributing to the success of the dairy industry in Uganda and East Africa; the role integration within the EAC has played in promoting this success; and the opportunities and challenges faced in the Ugandan dairy sector. Authors met with the Dairy Development Authority, the Ministry of Agriculture, Animal Industry and Fisheries, Jesa Farm Dairy Limited, and Brookside Limited. 


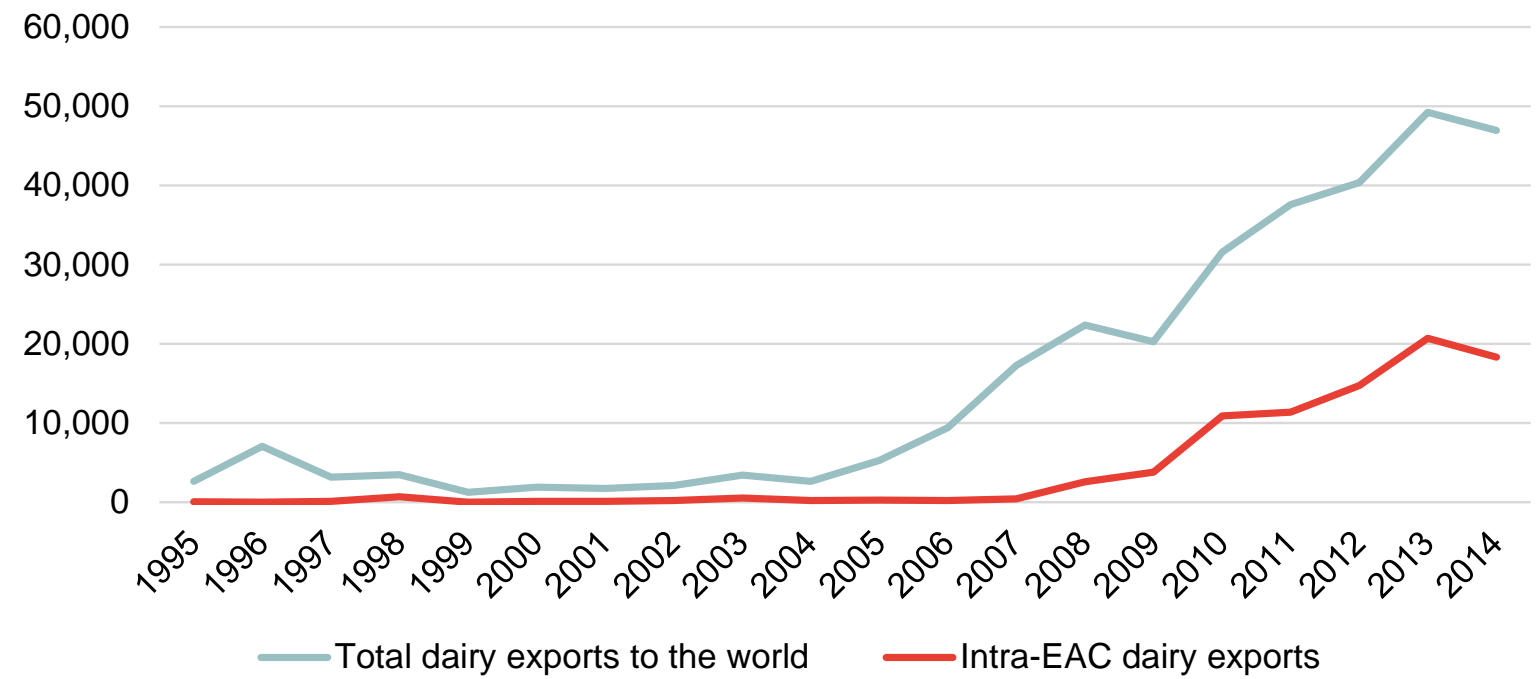

Source: authors' calculations based on UNCTADstat.

Less than 10 years ago the Ugandan dairy industry was still in its infancy. Uganda was a huge importer of dairy products (mainly from Kenya), despite the abundance of milk in the country. Today, Uganda is one of the major dairy-producing countries in Africa and the lead exporter of dairy products in the EAC. In 2014 Uganda contributed 48 per cent and 60 per cent to total EAC dairy product exports and total intra-EAC exports of dairy products, respectively. Uganda's dairy processing capacity increased from 330,000 litres per day in 2004 to 1,454,480 litres today (Bingi and Tondel 2015). The major players in milk processing are Brookside Limited (formerly Sameer Agriculture and Livestock Limited), Amos Dairies, Pearl Dairy, and Jesa Farm Dairy Limited.

In 2010 the country became a net exporter of dairy products. Uganda's exports of dairy products totalled approximately US $\$ 22.4$ million in 2014 , compared to only US $\$ 288,730$ in 2005 . Figure 10 shows the significant increase in Uganda's milk production over the last two decades.

Figure 10: Uganda's exports of milk, cream, and milk products (excluding butter and cheese) by destination (US $\$$ thousands)

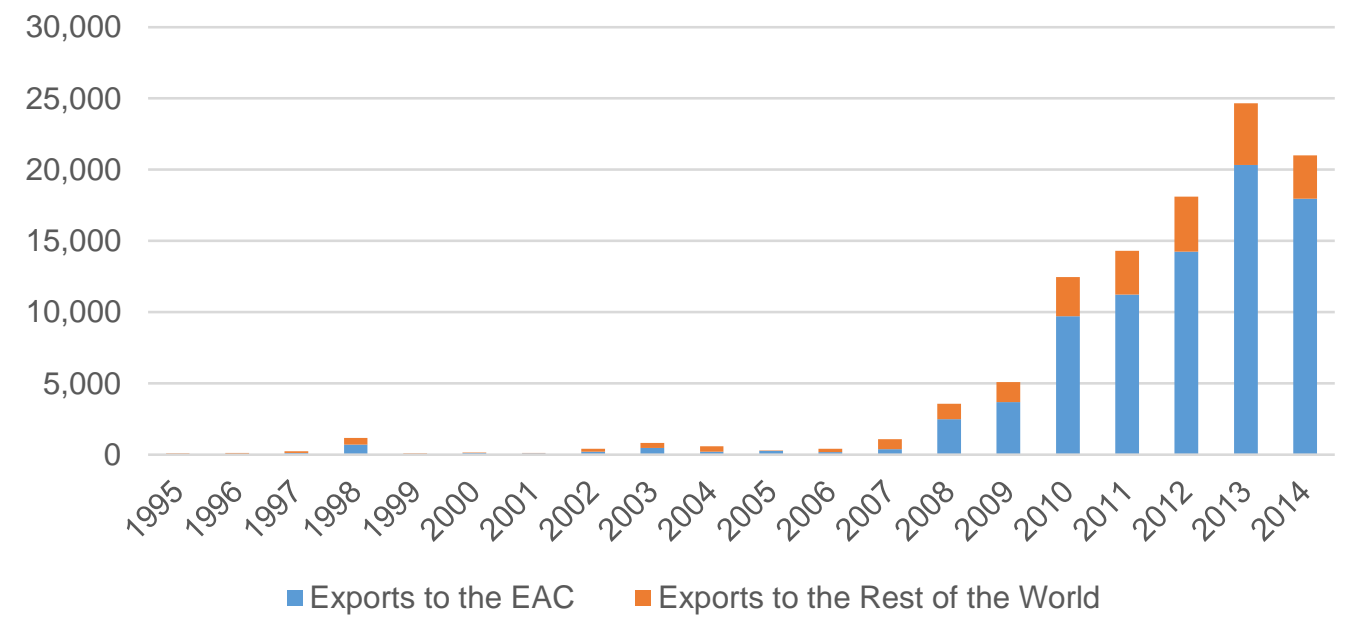

Source: ECA calculations based on UNCTADstat. 
Uganda actively participates in dairy RVCs in the EAC. This includes formal cross-border trade of processed milk products; informal cross-border trade of Uganda's exports of raw milk to Kenya for conversion into powder, pasteurized milk, and cream; imported inputs from Kenya such as packaging materials and spare parts; and cross-border mergers of East African dairy companies. In 2015, Kenya's Brookside Dairy Limited acquired Ugandan dairy company Sameer Agriculture and Livestock Limited. Kenyan processors previously largely imported powdered milk from European countries. However, with the introduction of the CU it is now cheaper to source milk locally from Uganda, process it into powder, and export it regionally (Daily Nation 2016).

Uganda also exports dairy products to markets beyond the EAC, including the US, India, and the Middle East. The country's farming systems are predominantly organic, which means that its dairy exports can pass stringent safety requirements in the US. With the exception of Nigeria and the Democratic Republic of the Congo, Uganda's exports of dairy products to African countries outside the EAC are limited. A CFTA would significantly reduce the costs of intra-African trade and provide opportunities for Uganda to tap into the continent's growing deficit in dairy products. Tetra Pak project Africa's milk deficit to triple from approximately 20,000 tonnes in 2012 to 120,000 tonnes in 2024, reflecting population growth, changing consumer prices, and a rise of the middle-income group (Tetra Pak 2014).

\subsection{The role of domestic policy}

Uganda's agroecological conditions and large number of cattle favour dairy production in most parts of the country and throughout the year. The country is also well-placed within the region to tap into the growing demand for dairy products associated with higher incomes. The government of Uganda has actively supported dairy production to take advantage of this potential.

The success story first started in 1993 when the government of Uganda, with assistance from the Danish International Development Agency, developed a Master Plan for the Dairy Sector. The plan delivered three key recommendations:

1 Milk marketing should be liberalized.

2 A Dairy Board should be created to oversee the liberalized industry.

3 The Dairy Corporation of Uganda that was established in 1967 should be privatized.

All of these recommendations were successfully implemented. The 1998 Dairy Industry Act created the National Dairy Development Authority (DDA), which is responsible for the development and regulatory functions of the dairy industry. The Dairy Corporation of Uganda was privatized in 2006 and taken over by Sameer Agriculture and Livestock Limited, now Brookside Limited. The liberalization of the dairy industry brought the monopoly of the Dairy Corporation to an end and opened up opportunities for private investment in the industry.

Since liberalization, the state has continued to promote the dairy sector through a number of programmes and policies. The Agriculture Sector Development Strategy and Investment Plan 2010/11-2014/15 identifies dairy cattle as a commodity to be promoted to support the development of value chains. The operations of the DDA are funded by the government of Uganda. Government financing is also channelled to the dairy sector through the National Agricultural Advisory Services (NAADS), which was created in 2001 to address the constraints of lack of access to agricultural information, knowledge, and improved technology among rural farmers. NAADS provides dairy farmers with extension services and supports the sector's shift from the use of rudimentary tools to modern tools. 
The National Agricultural Research Organisation was established in 2005 to guide and coordinate agricultural research activities in Uganda. The organization has supported the development of the dairy sector through spearheading the commercial production of fodder. At a more micro level, the Entebbe Dairy Training school builds productive capacities through providing free practical training on how to meet standards and pass quality-assurance tests.

Domestic policy has also focused on reducing the costs of engaging in dairy production. The provision of milk coolers and collection facilities has helped to enhance the safety of milk production and ensure that more milk reaches the final market. Public investment in rural infrastructure development such as rural feeder roads and the Rural Electrification Programme has contributed to improvements in milk quality through facilitating the quick delivery of farmers' milk to cooling centres. Costs to dairy investors have been reduced through the provision of free land (e.g. Amos Dairies) and tax holidays.

\subsection{The role of regional integration}

Regional policies and increased integration with the EAC have provided Uganda with opportunities to upscale production and serve the EAC dairy market.

Although the EAC does not have a specific regional policy for the dairy industry, partner states, in collaboration with the dairy regulatory authorities, have made significant progress in identifying areas and opportunities for cooperation and growth in the sector. The East Africa Dairy Regulatory Authorities Council (EADRAC) was established in 2006 under the framework of the EAC CU Protocol as a platform to facilitate the harmonization of dairy product regulations and standards in the region. The EADRAC comprises all EAC dairy regulatory authorities. Key areas of successful collaboration include trade in dairy products and conflict resolution, regional dairy industry sanitary standards, and regional dairy industry product standards. The harmonized standards are currently undergoing review to assess whether they are achieving the intended results.

Dairy products receive one of the highest levels of protection under the EAC CU sensitive items list, with a tariff rate of 60 per cent. This has helped to shelter the Ugandan dairy industry from excessive competition from trading partners outside the EAC, supported the expansion of dairy production in the country, and encouraged intra-EAC trade in dairy products. Eighty-two per cent of Uganda's dairy exports were destined for trading partners within the EAC in 2014.

Cross-border collaboration to improve regional infrastructure also played a crucial role in supporting trade and investment in the dairy sector, particularly for dairy products with a short shelf-life. Efforts to improve trade facilitation have also been an important support. The Electronic Single Windows in the EAC have significantly reduced the time and documentation requirements of cross-border trade. EAC members provide trade facilitation laboratory space at borders to test whether products meet the required standards.

\subsection{Challenges}

Despite the significant transformation of the Ugandan dairy industry over the last decade, continued success is not without challenges. The hygiene and handling practices at farm level in Uganda are generally poor, and despite a significant expansion in processing capacity, the majority of the country's milk still goes unprocessed. This reflects the still infant status and structure of the industry, but also offers significant scope for growth and upgrading (New Vision 2013).

Milk processing plants are currently underutilized due to the uneven distribution of plants, which are concentrated in Mbarara and Central Uganda. The country is investing heavily in processing 
plants to extend shelf-life and produce at higher levels of the value chain. This should help to rectify the uneven distribution of plants and boost the production of processed dairy products.

The DDA is supporting the drive for increased processing. The authority encourages smallholder farmers without access to pasteurizers to contact dairy processing companies to pasteurize their milk at a cost of US $\$ 25$ per tonne, before delivery to coolers. However, this fee is considered too high allow profit, particularly when some businesses and individuals still do not understand the health risks of raw milk and so prefer it over pasteurized products. There exists a significant price differential for local producers selling raw milk to the local market collection points (about UGX700 per litre) and selling to pasteurizers (only about UGX400 per litre), which further reduces incentives for pasteurizing. The authorities are planning to enhance the user-friendliness of negotiations between traders and processors to make processing options more accessible and cheaper for smallholder farmers. To avoid negative welfare impacts, it is crucial for this to be done before the government of Uganda bans the sale of raw milk, a provision that has been in the pipeline for years.

Elements of the domestic and external tax structures are holding back efforts to transform the dairy sector. In FY2014-15, the government of Uganda introduced a value added tax (VAT) of 18 per cent on processed milk, which was previously zero-rated. This has increased the price of processed milk and reduced incentives to produce and consume processed milk products. Raw milk sales are increasing, particularly in low-income households in urban areas. Dairy industry stakeholders organized by the Drink Milk Campaign have requested that the government remove VAT on processed milk on the grounds that milk belongs to a category of essential food and nutrition items that should not be taxed. The government of Uganda, however, remains in strong support of this use of VAT, arguing that the tax contributes significantly to revenues while only resulting in marginal price increases for locally packed and fresh milk; there is unlikely to be a reversal in policy. This places the Ugandan dairy industry at a disadvantage compared to Kenya, which has backtracked on plans to implement VAT on dairy products.

Although the EAC CET of 60 per cent on dairy products helps to protect Ugandan dairy producers, the high costs of importing key inputs into the dairy industry reduces the competitiveness of the sector. Uganda relies on imports of key inputs such as packaging materials, spare parts, and generators, the prices of which are increased by high taxes and high transport costs from the ports of Mombasa and Dar Es Salam.

\section{Conclusion}

Over the last decade a number of smokestack-free industries have emerged as important sources of export revenues and growth in the EAC. These include non-traditional manufactured products such as dairy products, pharmaceuticals, cigars and cigarettes, beverages, textiles, and horticulture, but also modern tradeable services such as tourism, financial services, and information and communications technology.

Integration within the EAC has helped to provide a supportive environment for the development of these industries. The CET provides for capital goods to be imported duty free, and the sensitive items list has helped to provide protection for regional producers of, for example, dairy products and cement, helping these industries grow over time. Regional bodies, policies, and projects have also supported the harmonization of practices in the region and helped to promote the EAC as an attractive destination for business and investment activity. Intra-EAC trade expanded significantly 
following the establishment of the CU. This trade is more diversified and embodies more manufactured products than the EAC's trade with the rest of the world.

That said, significant opportunities in smokestack-free industries still exist within the region that have not been fully exploited. The EAC regional integration project should be used to take advantage of these opportunities and position the region as a competitive economic bloc in the global trading system. The current CET structure means that some crucial intermediate inputs face very high tariff rates even though they are not sufficiently available locally. The CET structure needs to be reviewed to ensure that essential inputs can be sourced at rates that allow regional producers to operate competitively. Implementation of the CM Protocol should be fast-tracked. Although the free trade in goods within the region has contributed to the development of new RVCs, intra-EAC trade is still significantly hindered by NTBs and the slow liberalization of trade in services and capital markets. The Ugandan dairy industry highlights the importance of supportive domestic policies in order to harness potential comparative advantages and opportunities provided by increased regional integration.

\section{References}

African Review (2012). 'Kenyan Construction Boom Sees Sharp Rise in Steel Demand'. 9 June. Available at: www.africanreview.com/manufacturing/metals/kenyan-construction-boomsees-sharp-rise-in-steel-demand (accessed 7 December 2016).

Bingi, S., and F. Tondel (2015). 'Recent Developments in the Dairy Sector in Eastern Africa: Towards a Regional Policy Framework for Value Chain Development'. Economic Centre for Development Policy Management Briefing Note 78. Maastricht: Economic Centre for Development Policy Management.

Construction Review (2013). 'Africa's Growing Steel Industry'. 18 November. Available at: http://constructionreviewonline.com/2013/11/africas-growing-steel-industry (accessed 7 December 2016).

Daily Nation (2016). 'Kenya Imports Milk from Uganda to Meet Shortfall'. 21 September. Available at: www.nation.co.ke/lifestyle/smartcompany/Kenya-imports-milk-from-Uganda/12262879822-k3xgq6/index.html (accessed 7 December 2016).

EAC Gazette (2016). Complete volume. EAC Garette, AT1 (No. 5): 1-46.

EAC Secretariat (2014). Status of Elimination of Non-Tariff Barriers in the East African Community, Vol. 8. Arusha: East African Community Secretariat.

EastAfrican (2015). 'Reduced Duty on Imported Cement Sparks Furore Among EA Producers'. 28 February. Available at: www.theeastafrican.co.ke/news/2558-2638170-item-0nfikmw/index.html (accessed 15 December 2016).

EastAfrican (2016). 'EAC States Review CET to Protect Imported Goods from Double Taxation'. 25 June. Available at: www.theeastafrican.co.ke/business/EAC-states-review-CET-toprotect-imported-goods-double-taxes/2560-3267778-105c9ht/index.html (accessed 7 December 2016)

ECA (Economic Commission for Africa) (2012). Assessing Regional Integration in Africa V: Towards an African Continental Free Trade Area. Addis Ababa: United Nations Economic Commission for Africa.

Economist, The (2013). 'Get a Move On: Africa's Booming Economy Needs Modern Trade Routes'. 16 February. Available at: www.economist.com/news/middle-east-and-africa/21571920- 
africas-booming-economy-needs-modern-trade-routes-get-move (accessed 7 December 2016).

Economist, The (2016). 'East Africa's Used-clothes Trade Comes Under Fire'. 30 March. Available at: www.economist.com/news/middle-east-and-africa/21695819-governments-take-aimwell-meaning-foreigners-east-africas-used-clothes-trade (accessed 7 December 2016).

Frazer, G. (2012). 'The EAC Common External Tariff (CET) and Rwanda'. Working Paper. London: International Growth Centre.

Government of Uganda (n.d.). 'Policy Brief: Building Uganda's Position on the Review of EAC Common External Tariffs on Sensitive Products'.

Hoekman, B., and B. Shepherd (2016). 'Services, Firm Performance and Exports: The Case of the East African Community'. Working Paper. London: International Growth Centre.

ILEAP (International Lawyers and Economists Against Poverty) (2012). 'Trade in Services and Regional Integration: The Case of the EAC'. West Africa Regional Workshop on Trade in Services, 12 June.

Kitenga, G. (2012). 'There's Need to Review EAC's Common External Tariff. Standard Media, 11 September. Available at: www.standardmedia.co.ke/article/2000065917/there-s-need-toreview-eac-s-common-external-tariff (accessed 7 December 2016).

KNBS (Kenya National Bureau of Statistics) (2015). 'Statistical Abstract 2015'. Available at: www.knbs.or.ke/index.php?option $=$ com_content\&view $=$ article\&id=335:statisticalabstract $-2015 \&$ catid $=82 \&$ Itemid $=593$ (accessed 15 December 2015).

Mayer, T., and M. Thoenig (2016). 'Regional Trade Agreements and the Pacification of Eastern Africa'. Working Paper. London: International Growth Centre.

McIntyre, M.A. (2005). 'Trade Integration in the East Africa Community: An Assessment for Kenya'. Working Paper 05/143. Washington, DC: International Monetary Fund.

NBS (National Bureau of Statistics), Ministry of Finance Dar Es Salaam (2014). 'Statistical Abstract 2014'. Available at: www.nbs.go.tz/nbstz/index.php/english/tanzania-abstract/375statistical-abstract-2014 (accessed 15 December 2016).

New Vision (2013). 'Only 20\% of Uganda's Milk is Processed'. 28 June. Available at: www.newvision.co.ug/new_vision/news/1324360/-uganda-milk-processed (accessed 7 December 2016).

NISR (National Institute of Statistics of Rwanda) (2015). Statistical Yearbook 2015. Kigali: National Institute of Statistics of Rwanda.

Republic of Rwanda (2013). 'Economic Development and Poverty Reduction Strategy 2013-18: Shaping Our Development'. IMF Country Report 13/360. Washington, DC: IMF.

Soininen, I. (2014). 'The Continental Free Trade Area: What's Going On?’ Bridges Africa, 3(9): n.p.

Tetra Pak (2014). 'Tetra Pak Dairy Index: A Global Balancing Act—Dairy Supply and Demand'. October 2014. Available at: https:/ / endpoint895270.azureedge.net/static/documents/tetrapak_dairyindex_report_2014 .pdf (accessed 7 December 2016).

Transparency International (2012). 'Bribery as a Non-tariff Barrier to Trade: A Case Study of East African Trade Corridors'. Kenya: Transparency International.

UBOS (Uganda Bureau of Statistics) (2015). 'Statistical Abstract 2015'. Available at: www.ubos.org/onlinefiles/uploads/ubos/statistical_abstracts/Statistical\%20Abstract $\% 202$ 015.pdf (accessed 15 December 2015). 
World Bank, International Finance Corporation, and the East African Community Secretariat (2014). East African Common Market Scorecard 2014: Tracking EAC Compliance in the Movement of Capital, Services and Goods. Washington, DC: World Bank Group. 